\title{
Synergies and tensions between and within domestic and international market activities of firms
}

\author{
Maria Karafyllia \\ Lord Ashcroft International Business School, Anglia Ruskin University, East Road, CB1 1PT, \\ Cambridge, UK
}

Antonella Zucchella

University of Pavia, Via San Felice 5, Pavia 27100, Italy

\begin{abstract}
The distinction between domestic and international market activities has an idiosyncratic meaning for international business research. This study examines the significant yet unclear role of domestic market activities for the internationalizing firm through the theoretical lens of exploitation and exploration. By means of five qualitative case studies, we show that both the dynamics between domestic-international market activities and the interplay between exploitation-exploration are intrinsically concerned with synergies and tensions. Our findings uncover how firms leverage these synergies and manage these tensions that manifest between and within their domestic and international markets. Synergies and tensions are found to revolve around ambidexterity, networks and organizational market information processes.
\end{abstract}

Keywords: domestic; international; market activities; market exploitation; market exploration

\section{Introduction}

The domestic market often serves as a pre-stage for internationalization (Johanson \& Vahlne, 1977; Johanson \& Wiedersheim-Paul, 1975), and a profit sanctuary whilst the liabilities of foreignness are being overcome abroad (Hymer, 1976; Vernon, 1966). Domestic and international expansion can thus be conceived as two inseparable forms of firm growth (Bell et al., 2004; Luostarinen, 1979; Wolf, 1977). Domestic market activities are more likely to benefit international market activities of early internationalizers and to constrain international market activities of late internationalizers (Blomstermo et al., 2004). As firms get older, they develop mental models that hinder their ability to grow in new environments (Cohen \& Levinthal, 1990). However, complex domestic mindsets of large and established domestic firms, which experience environmental pressures to internationalize, facilitate their initial international steps (Nadkarni et al., 2011; Nadkarni \& Perez, 2007).

International business (IB) studies have sporadically identified synergies and tensions between and within domestic and international market activities of firms. Nevertheless, the role of the domestic market has remained nebulous (Nadkarni et al., 2011; Nadkarni \& Perez, 2007; Lu et al., 2014; Salomon \& Shaver, 2005). A thorough literature review reveals that the research question of what explains the emergence of synergies and tensions between and within domestic and 
international market activities has not been answered yet, and that such research might be supported by the theoretical perspective of exploitation and exploration. While the exploitation-exploration approach articulates complementarities and tradeoffs between exploitation and exploration, this approach can be applied to the market and the product domains (Voss \& Voss, 2013). This study finds that the dynamics between domestic and international markets, and the interplay between market exploitation and market exploration overlap. Our case study research illustrates how firms leverage exploitation and exploration synergies and manage exploitation and exploration tensions that unfold between and within domestic and international markets.

Specifically, we uncover a significant yet underexplored theme in international business research by means of the exploitation-exploration approach, which has surprisingly received limited scholarly attention in IB (Hsu et al., 2013). We consequently build theoretical links between domesticinternational market activities and market exploitation-exploration. Our empirical evidence provides support for these links and a framework for discussing synergies and tensions between domestic and international market exploitation and exploration. This novel perspective contributes to a more comprehensive understanding of international firm growth (cf. Bell et al., 2004; Luostarinen, 1979; Nadkarni et al., 2011; Wiedersheim-Paul et al., 1978; Wolf, 1977). At the same time, it contributes to the research calls for multi-level and multi-domain analyses of exploitation and exploration (Gupta et al., 2006; Raisch \& Birkinshaw, 2008; Turner et al., 2013). More importantly, this study reveals the overarching role of ambidexterity, networks, and organizational market information processes (OMIP), which all underlie the examined complementarities and tradeoffs.

In the following section, we unfold the synergies and tensions between domestic and international market activities that have already been identified in IB literature. Then we build the link with exploitation-exploration literature. Next, we outline the method of research before presenting and discussing the findings and implications. Finally, we draw conclusions.

\section{Theoretical background}

The origin of this research theme dates back in the early IB literature. In the product life-cycle model (Vernon, 1966), domestic activities can be a source of competitive advantage; innovation and production commence in the domestic market, before the market potential evolves abroad. Similarly, in the 1970's and 1980's, the various process models implicitly or explicitly considered domestic activities as an initial stage of the internationalization process, and perceived a synergy between preceding domestic expansion and first international steps. The most prominent example is Johanson \& Vahlne's (1977) internationalization model.

In Hymer's market power approach (1976), a multinational's capability for foreign investment initially depends on its domestic market power. When the performance potentials of domestic and international markets are compared, the domestic market is generally considered a profit sanctuary due to the absence of disadvantages of foreignness. On the other hand, superior international performance is expected when the firm has overcome the inherent disadvantages of foreignness and its firm specific advantages are stronger than those of its domestic competitors and the local international firms. For instance, before the Japanese firms developed lucrative international portfolios, they had had robust domestic performance; particularly in the 1970's, when they had been accumulating profits predominantly in their domestic market (Ito \& Rose, 2010).

Turning attention to theme specific studies, Wolf (1977) conceived domestic and international expansions as components of a single growth strategy. He showed that the domestic and international aspects of expansion share a common basis with respect to the firm's multifaceted innovation, production and marketing strategies. Whereas Luostarinen (1979) distinguished between home and overseas expansion, Wiedersheim-Paul et al. (1978) developed a pre-export behavioral model that shed light on the role of domestic activities in the start of the internationalization process. Bell et al. 
(2004) emphasized the role of knowledge intensity in domestic and international activities of UK SMEs. Drawing on the argument that internationalisation is part of and inseparable from the overall firm growth and development (Bell \& Young, 1998), proactive product and market specific strategies both domestically and internationally, and rapid internationalization were more evident in UK knowledge intensive SMEs as compared to UK traditional and family-owned SMEs.

Casson (1992) highlighted the distinction between domestic and international marketing knowhow. He stressed transaction costs in knowledge transfer between different activities and locations. The author argued that whereas technical knowledge is universal in its geographical coverage, market knowledge is location specific. McNaughton \& Bell (2001) found that the channel used by small knowledge intensive companies in the domestic market is usually extended to their international markets. This synergy between domestic and international channel decisions was attributed to anticipated economies of scale, to similar characteristics between domestic and international products and to strategic momentum from the domestic market. Salomon \& Shaver (2005) tested the interrelationships between export and domestic sales, hypothesising that they are determined simultaneously. Whilst domestic and export sales were found to be substitutes for Spanish foreign-owned firms, domestic and export sales were found to be complementary for smaller, Spanish-owned firms. Lu, Liu, Filatotchev \& Wright (2014) found that domestic industrial and domestic regional diversification positively influences international diversification of Chinese listed firms. They demonstrated that the impact of domestic diversification is increased by top management team's international experiences, whereas top management team's political network weakens the effect of domestic diversification on international diversification of firms.

As far as early internationalization is concerned, early internationalizers are argued to possess learning advantages of newness, whereas older entrants are suggested to face learning liabilities (Autio, Sapienza, \& Almeida, 2000; Sapienza et al., 2006; Zahra, Ireland, \& Hitt, 2000). Late internationalizers therefore have to restructure their existing processes in order to learn and grow in new dynamic environments, such as international markets. However, their ability to change is hampered by cognitive, structural and positional patterns developed during domestic activities. In a similar vein, Blomstermo et al. (2004) proposed that prior domestic experience benefits the international knowledge development of early internationalizers but hinders the international knowledge development of late internationalizers.

Nadkarni \& Perez (2007) and Nadkarni et al. (2011) furthermore clarified the synergies between domestic mindsets and initial international steps of large and established domestic firms that experienced environmental pressures to internationalize. Nadkarni \& Perez (2007) contended that complex domestic mindsets of top managers developed through domestic resource diversity and domestic action complexity could assist firms to identify crucial differences between domestic and international markets, and leverage domestic resources in international markets. Accordingly, firms with complex domestic mindsets could better envisage the type and sources of critical international market information and could therefore acquire it more quickly and less costly. Nadkarni et al. (2011) also claimed that the match between domestic mindsets and international industry conditions maximizes early international performance. Depth and breadth of domestic mindsets were found to affect differently early international performance in global, multidomestic, and transnational industries.

McDougall (1989) and McDougall et al. (2003) suggested two separate firm behaviors and structures, namely domestic and international, after studying new venture firms that operated entirely in the domestic market (DNVs), and new venture firms that began to receive revenues from international markets (INVs). DNVs were associated with strategies of production expansion and customer specialisation, and INVs were associated with strategies of broader market coverage through accessing numerous distribution channels and targeting diverse market segments. Prior technical experience of top management teams was negatively related to overseas activities, and the decision-makers of DNVs were mainly scientists with highly technical backgrounds. Indeed, technical entrepreneurs are mainly interested in product and production development, and 
internationalization may occur as a result of these activities; whereas marketing entrepreneurs are more proactive in internationalization (Andersson, 1990).

Dimitratos et al. (2004) brought environmental determinism into the picture. They showed that alignment of entrepreneurship with domestic environmental conditions can strengthen international performance. Consequently, market selection that matches uncertain domestic market conditions may result in superior international performance. In addition, such market selection is likely to improve market learning processes (Williamson, 1997). Liu et al. (2014) indicated synergetic effects between domestic learning and host market learning, which jointly shape subsidiary performance. Sapienza et al. (2005) found that the more internationalized is the firm, the less attention pays to domestic market learning. Early internationalization and entrepreneurial orientation may promote an organizational learning culture pertaining to both domestic and international activities. De Clercq et al. (2005) found that although international and domestic learning activities of Belgian SMEs' seem to be complementary; when SMEs from a small domestic economy commit their effort to domestic learning activities, they might be less likely to internationalize further. Sigfusson \& Harris (2013) corroborated the above finding from a network perspective. They asserted that strong domestic relationships divert resources from the internationalization effort of high technology INVs. Whilst a domestic market discourages the building of internationalization networking capability, high tech entrepreneurs without a domestic market are more likely to build international relationships more actively.

Table 1 summarizes the diverse facets of domestic and international market activities that have been studied by extant research. Scholars have explicitly or implicitly identified synergies and tensions, with the amount of synergies exceeding that of tensions in accordance with the early IB literature. Table 1 also shows that the theme related findings have largely been consistent across studies. In some cases, a link between synergies or tensions and specific organizational characteristics, such as age, size, industry, and age at first international entry, has been suggested.

This literature review showed that although this is a fundamental IB issue, the research question of what explains the emergence of synergies and tensions between and within domestic and international market activities has not been answered yet. In this respect, it has not been examined how the synergies and tensions that unfold within the same (domestic or international) market of a firm (cf. Sapienza et al., 2005; De Clercq et al., 2005) relate to the synergies and tensions that manifest between domestic and international activities. The within-market complementarities and tradeoffs could perhaps provide a better understanding and more complete account of the cross-market synergies and tensions.

In order to investigate our research question, an appropriate theoretical lens should facilitate the study of market synergies and tensions. We therefore take an exploitation-exploration approach, which is intrinsically concerned with market synergies and tensions (Kyriakopoulos \& Moorman, 2004; Voss \& Voss, 2013), and it has not been applied to theme specific research before. While firms leverage synergies and manage tensions between and within domestic and international market activities, they simultaneously reconcile market exploitation-exploration tensions and generate market exploitation-exploration synergies in the pursuit of organizational viability. Through the theoretical perspective of exploitation and exploration, we seek to reveal interesting underlying patterns concerning synergies and tensions between and within domestic and international market activities. Hence, we turn to the exploitation-exploration literature so as to build the theoretical links between the theme and the theoretical lens of our study. 
Table 1

The joint investigation of domestic and international market activities of firms in the existing literature

\begin{tabular}{ll}
\hline Studies & $\begin{array}{l}\text { Jointly investigated aspects of } \\
\text { domestic and international market } \\
\text { activities }\end{array}$
\end{tabular}

Bell et al. (2004);

Luostarinen (1979);

McNaughton \& Bell (2001);

Wiedersheim-Paul et al.

(1978)

Lu et al. (2014); Wolf (1977)

Domestic \& international diversification

Salomon \& Shaver (2005) Domestic \& export sales

Blomstermo et al. (2004)

Nadkarni \& Perez (2007);

Nadkarni et al. (2011)

McDougall (1989);

McDougall et al. (2003);

Spence, Orser \& Riding

(2011)

Dimitratos et al. (2004)

Liu et al. (2014)

Sapienza et al. (2005)

De Clercq et al. (2005)

Sigfusson \& Harris (2013)
Domestic \& international expansion

Synergies concerning product \& market specific strategies
Length of domestic market activities \& international knowledge development

Complexity of domestic mindsets, domestic resource diversity, domestic action complexity \& early international entry modes and early international performance

Domestic \& international new ventures

Domestic environmental uncertainty \& international performance

Domestic learning, host market learning \& subsidiary performance

Degree of internationalization, age at first international entry \& domestic learning effort

Domestic learning effort \& internationalization intent

Domestic networks \& international relationship development activeness and international relationship development capabilities
Synergies concerning the development of market knowledge and capabilities

Synergies for smaller, local firms; tensions for larger, foreign-owned firms

Synergies for early internationalizers; tensions for late internationalizers

Synergies for large and established domestic firms

Prior technical experience of top management teams contributes to tensions

Synergy: alignment of entrepreneurship with domestic uncertain environmental conditions strengthens international performance

Synergies between domestic learning and host market learning

Synergy between early internationalization and domestic learning effort; tension between degree of internationalization and domestic learning effort

Tensions for SMEs from a small domestic economy

Tensions for born-global software ventures 


\section{Domestic and international market exploitation and exploration}

In his seminal paper, March (1991, p. 71) defined exploitation as 'refinement, choice, production, efficiency, selection, implementation and execution', and exploration as 'search, variation, risk-taking, experimentation, play, flexibility, discovery, and innovation'. Since then, research on both use and refinement of existing knowledge (exploitation) and creation of new knowledge (exploration) has proliferated (Stadler et al., 2014; Turner et al., 2013). Exploration has been related to organic structures, autonomy, improvisation, and emerging markets and technologies; on the other hand, exploitation has been related to mechanistic structures, control, routinization, and established markets and technologies (He \& Wong, 2004).

Although difficult to attain, equal dexterity in exploitation and exploration fosters organizational viability (Lubatkin et al., 2006). The exploitation-exploration tensions emanate from the need to manage the opposing resource requirements and different knowledge management processes of exploitation and exploration (Andriopoulos \& Lewis, 2009; March, 1991). Organizational ambidexterity refers to a firm's ability to manage these tensions (Duncan, 1976). Levinthal \& March (1993) referred to ambidexterity as the problem of simultaneous and sufficient engagement with both exploitation, to ensure current viability, and exploration to ensure future viability. Structurally ambidextrous firms, which hold organizational units with a single focus on either exploitation or exploration, face the additional challenge of coordinating and integrating the different knowledge management processes of exploitation and exploration across separate functional units (O'Reilly \& Tushman, 2004). In other words, firms can attain organizational ambidexterity by combining exploration and exploitation across or within business units, which often have a product and/or market focus.

Exploitation and exploration can thus manifest in the product and market domains (Voss \& Voss, 2013). Tensions particularly intensify when exploitation and exploration are found within the same domain (Gupta et al., 2006). In alignment with our research question, the concepts of market exploitation and exploration guide our study. 'Market exploration targets new customers outside of the currently served market. New customers may represent an emerging market or an existing but non-targeted market - for example, a new geographic market or a broadening of the target market to include additional sociodemographic (e.g., retirees versus yuppies) market segments' (Voss \& Voss, 2013, p. 1461). On the other hand, market exploitation emphasizes the refinement and deployment of knowledge about a firm's existing customers, competitors, suppliers and distributors (Kyriakopoulos \& Moorman, 2004).

We furthermore distinguish between domestic and international market exploitation, and between domestic and international market exploration (cf. Hsu et al., 2013; Lisboa et al., 2013; Prange \& Verdier, 2011). Domestic market exploitation involves refinement and deployment of knowledge about customers, competitors, and partners in existing domestic markets, whereas domestic market exploration refers to generation of knowledge about customers, competitors and partners in new domestic markets. International market exploitation signifies a firm's path-dependent development and deployment of knowledge about customers, competitors and partners in existing international markets. Conversely, international market exploration relates to creation of knowledge about customers, competitors and partners in new international markets. We thus examine exploitation and exploration in domestic and international markets.

This study elucidates the oblique role of the domestic market for the internationalizing firm through an exploitation-exploration approach. We show how the dynamics between domestic and international markets and the interplay between market exploitation and exploration overlap. In order to explain how synergies and tensions between and within domestic and international market activities emerge, we illustrate how firms leverage exploitation and exploration complementarities 
and manage exploitation and exploration tradeoffs that manifest between and within their domestic and international markets. The next section discusses our research methodology.

\section{Methodology}

\subsection{Case selection}

Given that our research question investigates the nature rather than the frequency of a phenomenon, qualitative and not quantitative methods are appropriate (Ghauri, 2004; Ghauri \& Grønhaug, 2005; Piekkari et al., 2009). Five UK firms were initially chosen for case analysis applying the principle of purposeful rather than random sampling (cf. Harris \& Sutton, 1986; Patton, 2005; Pettigrew, 1990). We selected the UK small and medium-sized enterprise (SME) as an appropriate research site for studying the synergies and tensions between domestic and international market exploitation and exploration. Market exploitation-exploration tensions within SMEs are of particular theoretical and managerial relevance, and warrant research inquiry. As compared with their larger counterparts, SMEs face additional resource constraints on creating structures that facilitate resource allocation between the opposing activities of exploitation and exploration (Voss \& Voss, 2013). As a result, tensions escalate, especially when SMEs implement exploitation and exploration within a single domain, such as the market one.

With regard to the domestic market setting, Nadkarni \& Perez (2007) studied U.S. firms and their findings suggested the significance of a complex domestic market, in terms of competition and customers' requirements, for the joint investigation of domestic and international market activities. IB research has often classified the UK and U.S. markets in the same group, and it has been puzzled with the international performance of UK firms. Westhead et al.'s $(2002,2004)$ representative studies in the UK SME sector found that only a minority of British SMEs were exporters and only a small proportion of their sales derived from the international marketplace. Indeed, the international underperformance of UK firms has been widely reported as compared to firms from other advanced economies, such as Germany, Italy, Canada, the U.S. and Japan (Beamish et al., 1993; Diamantopoulos \& Schlegelmilch, 1994; McGuinness et al., 1991; Morgan \& Katsikeas, 1998). This makes the UK SME an interesting setting for our research.

Voss \& Voss (2013) furthermore emphasized the enabling or constraining role of organizational characteristics in implementation of strategic combinations of exploitation and exploration. Prange \& Verdier (2011) suggested the examination of exploitation and exploration in internationalization according to the industry type. In a similar vein, Andriopoulos \& Lewis' (2009) cases on exploitationexploration tensions also exhibited variation in terms of age, size and industry specialization. Finally, owing to our research question, the five case companies demonstrated diverse durations of domestic and international market activities, and degrees of internationalization. They had also been featured in the press as either high-performing companies or rising stars with distinct competences. As such, they were deemed as appropriate cases for investigating exploitation-exploration synergies and tensions. Table 2 presents the organizational characteristics of the five case companies. Their names have been anonymized for confidentiality reasons ${ }^{1}$.

\footnotetext{
${ }^{1}$ Similarly, the specific names of products, customers, partners and competitors, and chronological placement of distinctive corporate activities and achievements have not been disclosed in Section 4.
} 
Table 2

Case companies

\begin{tabular}{|c|c|c|c|c|c|c|c|}
\hline SME & Industry & $\begin{array}{l}\text { No. of } \\
\text { employ } \\
\text { ees }\end{array}$ & Age & $\begin{array}{l}\text { No. of years } \\
\text { domestically }\end{array}$ & $\begin{array}{l}\text { No. of years } \\
\text { internationally }\end{array}$ & $\begin{array}{l}\text { International- } \\
\text { to-total sales } \\
\text { ratio }\end{array}$ & $\begin{array}{l}\text { No. of } \\
\text { international } \\
\text { countries }\end{array}$ \\
\hline
\end{tabular}

\begin{tabular}{|c|c|c|c|c|c|c|c|}
\hline MED & Medical Devices & 237 & 35 & 33 & 35 & $88 \%$ & 67 \\
\hline CRM & CRM Software & 124 & 26 & 26 & 15 & $73 \%$ & 23 \\
\hline Sportswear & Sportswear & 171 & 47 & 47 & 46 & $57 \%$ & 61 \\
\hline Infosyst & $\begin{array}{l}\text { Information } \\
\text { Systems } \\
\text { oil/gas/aviation }\end{array}$ & 85 & 20 & 20 & 10 & $21 \%$ & 5 \\
\hline Optolect & $\begin{array}{l}\text { Compound } \\
\text { semiconductor } \\
\text { foundry }\end{array}$ & 31 & 14 & 14 & 14 & $46 \%$ & 14 \\
\hline
\end{tabular}

\subsection{Data collection}

The data collection was intensive and lasted nine months (from June 2007 to March 2008). It produced a vast amount of data from semi-structured interviews, archival data and observation. A stage-by-stage process of data collection was followed, which links to the concept of 'stream of research' and the combination of different data sources over time (Carson \& Coviello, 1996; Davis et al., 1985). There were three stages in our data collection that are described below.

Stage 1. This was the 'drift' phase and extended over three months. Stage 1 was heavily based on the study of archival data, on-site observation and conversations with companies' staff across levels, disciplines and tenure. Archival data included industry reports, external articles on the case companies, company documentation, marketing material, and company press releases. Staff's daily routines and social interactions, especially in relation to firms' domestic and international market activities (e.g., calls with customers and distributors, team meetings on market strategy, impromptu discussions among staff), were observed. Insights were converted into detailed field notes on the same day, as Eisenhardt and Bourgeois' (1988) 24-hour rule recommends. Overall, the stage-one data collection focused on company history and structure, past and current market activities, and relationships within marketing and sales teams, and with customers, competitors and partners. This "soaking-in" phase generated an understanding of both the organizational context, and market exploitation and exploration in each case company, which facilitated the subsequent in-depth interviews with key actors (Van Maanen, 2011).

Stage 2. The second stage of the data collection lasted four months and involved in-depth interviews. A total of 17 detailed, in-depth interviews were conducted with key organizational members. The identification of respondents was based on a snowballing technique and followed recommendations by Huber \& Power (1985) for improving the accuracy of retrospective reports. The first in-depth interview in each case was conducted with the firm's Managing Director, whom was asked to nominate key informants who could provide further insight. Two to three interviews were 
subsequently carried out with organizational members, such as chairmen, sales directors, financial directors and marketing directors. Within each case company, the last interview failed to reveal new or dispute existing themes or relationships, that is, theoretical saturation was achieved (Strauss \& Corbin, 1990). All interviews lasted 70 minutes on average, and were recorded and transcribed to ensure reliability (Eisenhardt \& Bourgeois, 1988). Notes were also taken and written up immediately after the interviews.

Following Glaser \& Strauss (2009), the interview protocol was initially generic and gradually became more focused. The interviews began with general open-ended questions on external environment and how it affected market development. Interviewees elaborated on differences and similarities among their domestic and international markets and how those affected their firm's way of doing business domestically and internationally. Interviewees were probed to discuss and provide examples of the role of market information in firm's development within existing and new markets. Informants' examples referred to market knowledge management processes, market consolidation, and discovery and enactment of new market opportunities concerning both domestic and international markets.

Stage 3. The third 'probing' stage lasted two months. In this phase, follow-up interviews and discussions, observation, and archival data were used as means of investigating further the research question and refining the understanding developed at the previous stage. A core aspect of this phase was the write-up of case reports and managing directors' comments on them. Case reports referred to examples of exploitation and exploration within the domestic or international markets, and exploitation and exploration between the domestic and international markets. Having in mind synergies and tensions but without mentioning these terms and their synonyms during follow-up interviews, we also probed into allocation of resources, such as staff, time and finance, between new and existing market segments, both domestic and international.

Table 3 compiles the list of the data sources for each case company. 
Table 3

Data Sources

\begin{tabular}{|c|c|c|c|}
\hline Case Company & Interviews $^{\mathrm{a}}$ & Archival material ${ }^{b}$ & Observation \\
\hline MED & $\begin{array}{l}\text { Managing Director (2) } \\
\text { Chairman (2) } \\
\text { Sales Director (4) } \\
\text { Total: } 8\end{array}$ & $\begin{array}{l}\text { Company handbook } \\
\text { Company press } \\
\text { releases } \\
\text { Corporate reports } \\
\text { (sales) } \\
\text { Marketing material } \\
\text { Articles } \\
\text { Industry report }\end{array}$ & $\begin{array}{l}\text { Once biweekly for } \\
\text { three plus two months } \\
\text { (Data collection - } \\
\text { Stages } 1 \text { \& 2) }\end{array}$ \\
\hline CRM & $\begin{array}{l}\text { Managing Director (2) } \\
\text { Financial Director (2) } \\
\text { Marketing \& Sales } \\
\text { Director (3) } \\
\text { UK Project Manager (2) } \\
\text { Total: } 9\end{array}$ & $\begin{array}{l}\text { Company handbook } \\
\text { Company press } \\
\text { releases } \\
\text { Corporate reports } \\
\text { (financial; marketing \& } \\
\text { sales; UK projects) } \\
\text { Marketing material } \\
\text { Articles } \\
\text { Industry report }\end{array}$ & $\begin{array}{l}\text { Once biweekly for } \\
\text { three plus two months } \\
\text { (Data collection - } \\
\text { Stages } 1 \text { \& 2) }\end{array}$ \\
\hline Sportswear & $\begin{array}{l}\text { Managing Director (2) } \\
\text { Financial Director (2) } \\
\text { Sales Director (3) } \\
\text { Total: } 7\end{array}$ & $\begin{array}{l}\text { Company handbook } \\
\text { Company press } \\
\text { releases } \\
\text { Corporate reports } \\
\text { (financial; sales) } \\
\text { Marketing material } \\
\text { Articles } \\
\text { Industry report }\end{array}$ & $\begin{array}{l}\text { Once biweekly for } \\
\text { three plus two months } \\
\text { (Data collection - } \\
\text { Stages } 1 \& 2 \text { ) }\end{array}$ \\
\hline Infosyst & $\begin{array}{l}\text { Managing Director (3) } \\
\text { Financial Director (2) } \\
\text { Human Resources } \\
\text { Manager (2) } \\
\text { Total: } 7\end{array}$ & $\begin{array}{l}\text { Company handbook } \\
\text { Company press } \\
\text { releases } \\
\text { Corporate reports } \\
\text { (financial; sales) } \\
\text { Marketing material } \\
\text { Articles } \\
\text { Industry report }\end{array}$ & $\begin{array}{l}\text { Once biweekly for } \\
\text { three plus two months } \\
\text { (Data collection - } \\
\text { Stages } 1 \text { \& 2) }\end{array}$ \\
\hline Optolect & $\begin{array}{l}\text { Managing Director (2) } \\
\text { Financial Director (2) } \\
\text { Operations Director (2) } \\
\text { R\&D Director (2) } \\
\text { Total: } 8\end{array}$ & $\begin{array}{l}\text { Company handbook } \\
\text { Corporate reports } \\
\text { (financial; sales) } \\
\text { Articles } \\
\text { Industry report } \\
\end{array}$ & $\begin{array}{l}\text { Once biweekly for } \\
\text { three plus two months } \\
\text { (Data collection - } \\
\text { Stages } 1 \& 2 \text { ) }\end{array}$ \\
\hline
\end{tabular}

aThis column summarizes the corporate roles of informants and the number of interviews throughout the three data collection stages.

bThis column summarizes the types of archival or secondary data collected for each case company.

\subsection{Data analysis}

Drawing on Glaser \& Strauss (2009) and Miles \& Huberman (1994), we followed a two-stage data analysis process, which is explained below. Figure 1 depicts the data structure and Table 4 summarizes the respective definitions (see also Section 3) used in the data analysis. 


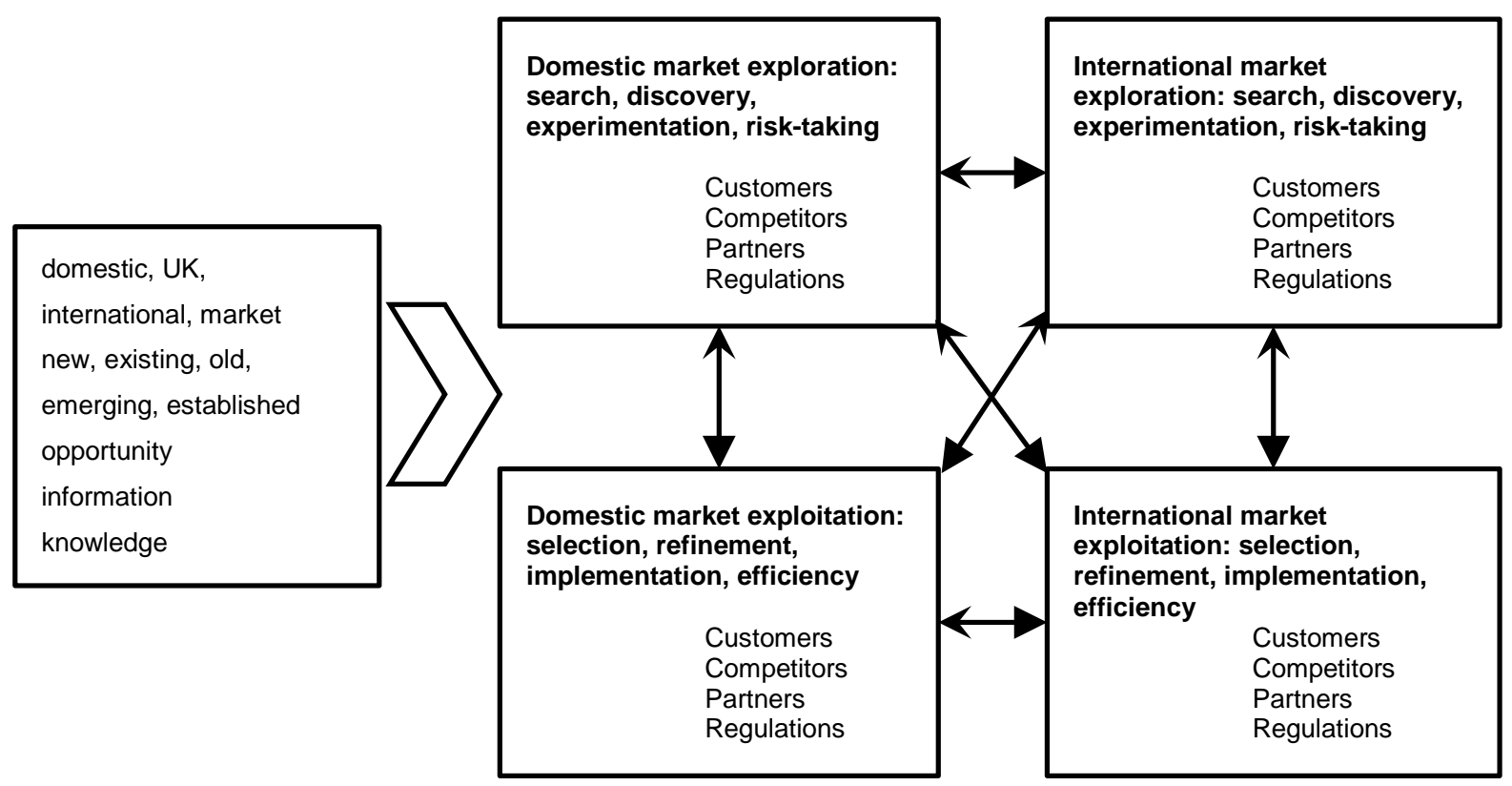

Fig. 1. Data structure

Stage 1. We initially identified the notions of domestic and international market exploitation and exploration within each case. We located specific words within our unstructured data, such as domestic, UK, international, market, new, existing, old, emerging, established, opportunity, information and knowledge. We used in vivo coding, that is, we assigned the concepts based on words or short phrases in the interview transcripts (Strauss \& Corbin, 1990). For reliability purposes, we compared two coders' codings with an intercoder agreement of $\mathrm{k}=0.81$ (Cohen, 1960). Disagreements between the coders were discussed and resolved. We identified the notions of domestic and international market exploitation and exploration in 35 out of 39 interviews across all case companies and stages of data collection.

Stage 2. We subsequently looked for relationships between the concepts within and across cases (Miles \& Huberman, 1994). The synergies and tensions inductively emerged from the data rather than a priori hypotheses (Strauss \& Corbin, 1990). Returning to the theoretical links developed in Section 2, our data structure (Figure 1) revealed that cross-market synergies and tensions intertwine with synergies and tensions that manifest within the same market. It is worth noting that we also identified product exploitation and product exploration during Stage 1 of the data analysis. Nevertheless, Stage 2 did not reveal any relationship between product exploitation-exploration and domesticinternational market activities. We attribute this result to the fact that the products of each case firm did not differ between its domestic and international markets. In this stage, we again compared two coders' codings with an intercoder agreement of $\mathrm{k}=0.89$ (Cohen, 1960). Disagreements between the coders were discussed and resolved. The two authors extensively discussed the emerged relationships and interpretations of the data, while consulting existing literature to refine their understanding. We focused on the most robust results that find wider support within the amount of data collected (i.e., they were reported in more than one interviews or they were reported in at least one interview and also supported by archival data and/or observation). 
Table 4

Definitions

\begin{tabular}{|c|c|c|}
\hline Concepts & Definitions & Key references \\
\hline Domestic market exploration & $\begin{array}{l}\text { Generation of knowledge about } \\
\text { customers, competitors and } \\
\text { partners in new domestic } \\
\text { markets }\end{array}$ & $\begin{array}{l}\text { Hsu et al. (2013) } \\
\text { Lisboa et al. (2013) } \\
\text { Prange \& Verdier (2011) } \\
\text { Voss \& Voss (2013) }\end{array}$ \\
\hline Domestic market exploitation & $\begin{array}{l}\text { Refinement and deployment of } \\
\text { knowledge about customers, } \\
\text { competitors, and partners in } \\
\text { existing domestic markets }\end{array}$ & $\begin{array}{l}\text { Hsu et al. (2013) } \\
\text { Kyriakopoulos \& Moorman } \\
\text { (2004) } \\
\text { Lisboa et al. (2013) } \\
\text { Prange \& Verdier (2011) }\end{array}$ \\
\hline International market exploration & $\begin{array}{l}\text { Creation of knowledge about } \\
\text { customers, competitors and } \\
\text { partners in new international } \\
\text { markets }\end{array}$ & $\begin{array}{l}\text { Hsu et al. (2013) } \\
\text { Lisboa et al. (2013) } \\
\text { Prange \& Verdier (2011) } \\
\text { Voss \& Voss (2013) }\end{array}$ \\
\hline $\begin{array}{l}\text { International market } \\
\text { exploitation }\end{array}$ & $\begin{array}{l}\text { Development and deployment of } \\
\text { knowledge about customers, } \\
\text { competitors and partners in } \\
\text { existing international markets }\end{array}$ & $\begin{array}{l}\text { Hsu et al. (2013) } \\
\text { Kyriakopoulos \& Moorman } \\
\text { (2004) } \\
\text { Lisboa et al. (2013) } \\
\text { Prange \& Verdier (2011) }\end{array}$ \\
\hline Integration & $\begin{array}{l}\text { Engagement with both poles of a } \\
\text { combination of domestic and } \\
\text { international market } \\
\text { exploitation and exploration }\end{array}$ & $\begin{array}{l}\text { Lawrence \& Lorsch (1967) } \\
\text { Jansen et al. (2009) }\end{array}$ \\
\hline Differentiation & $\begin{array}{l}\text { Engagement with either poles of } \\
\text { a combination of domestic and } \\
\text { international market } \\
\text { exploitation and exploration }\end{array}$ & $\begin{array}{l}\text { Lawrence \& Lorsch (1967) } \\
\text { Jansen et al. (2009) }\end{array}$ \\
\hline Ambidexterity & $\begin{array}{l}\text { A firm's ability to engage } \\
\text { simultaneously and sufficiently } \\
\text { with both exploitation, to ensure } \\
\text { current viability, and exploration } \\
\text { to ensure future viability }\end{array}$ & $\begin{array}{l}\text { Andriopoulos \& Lewis (2009) } \\
\text { Levinthal \& March (1993) }\end{array}$ \\
\hline Strength of a tie & $\begin{array}{l}\text { A combination of the amount of } \\
\text { time, the emotional intensity, the } \\
\text { intimacy, and the reciprocal } \\
\text { services which characterize the } \\
\text { tie }\end{array}$ & $\begin{array}{l}\text { Granovetter (1973, p. 1361) } \\
\text { Stadler et al. (2014) } \\
\text { Tiwana (2008) } \\
\text { Turner et al. (2013) }\end{array}$ \\
\hline $\begin{array}{l}\text { Organizational market } \\
\text { information processes (OMIP) }\end{array}$ & $\begin{array}{l}\text { Acquisition, dissemination, } \\
\text { sensemaking and application of } \\
\text { market information }\end{array}$ & $\begin{array}{l}\text { Kyriakopoulos \& Moorman } \\
\text { (2004) } \\
\text { Moorman (1995) }\end{array}$ \\
\hline
\end{tabular}




\subsection{Illustrating the combinations of exploitation and exploration between and within domestic and international markets}

Following our data structure (Figure 1) and building upon Voss \& Voss (2013), Figure 2 captures the combinations of exploitation and exploration that manifest between and within domestic and international markets: (a) exploitation and exploration within a single market domain; (b) crossmarket exploitation and exploration; and (c) exploitation between domestic and international markets and exploration between domestic and international markets. Sole exploration explores new domestic and international market segments, and sole exploitation exploits existing domestic and international customer markets. Firms could attain domestic or international market ambidexterity by combining exploration and exploitation within a single market domain. Cross-market ambidexterity captures the combinations of exploration of new domestic or international markets and exploitation of current international or domestic markets, respectively. The application of this framework concerns specific market opportunities and resulting synergies and tensions rather than firm-level market exploitation and exploration. We use this classification scheme in order to depict the six exploitation-exploration combinations and facilitate the discussion in the next section.

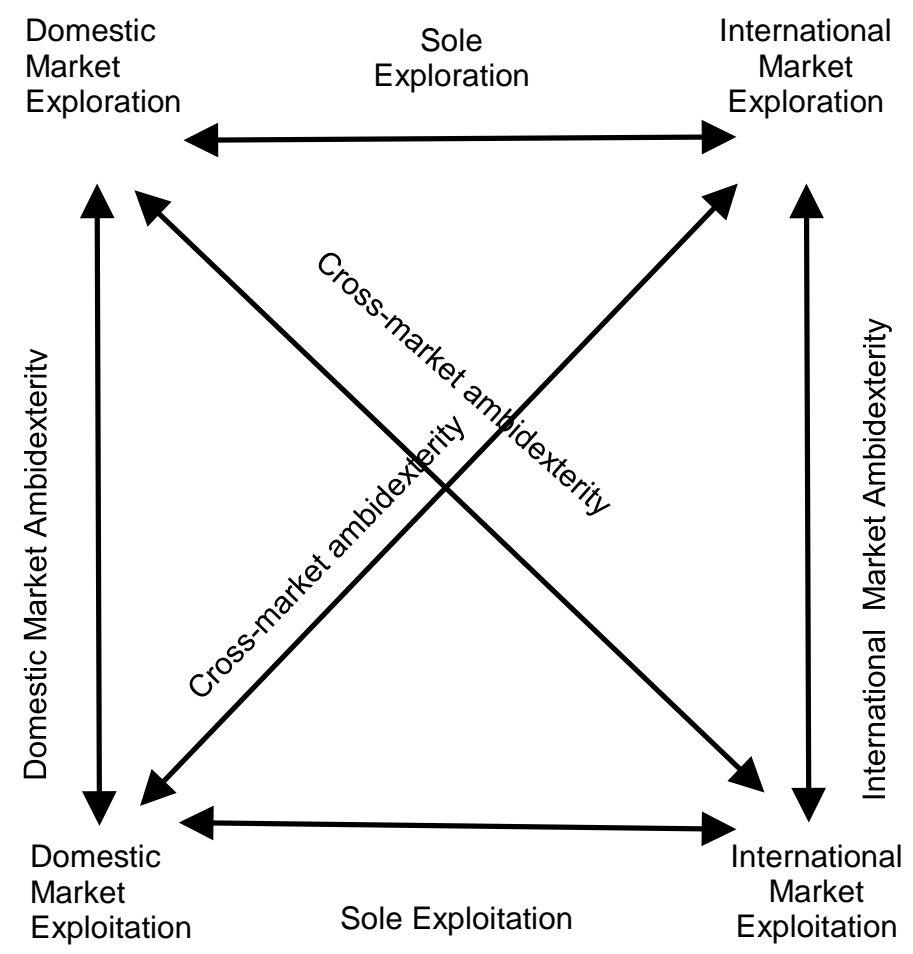

Fig. 2. Domestic and international market exploitation and exploration

Before discussing the implications of our study, we present and analyze our findings in the next section. The following analysis then illustrates how firms leverage exploitation-exploration synergies and manage exploitation-exploration trade-offs between and within their domestic and international markets. 


\section{Findings: leveraging synergies and managing tensions}

All the case firms, except one, regarded their domestic and international markets as similarly challenging. The UK represented a "demanding" (Infosyst, Managing Director), "very competitive" (MED, Chairman) and "sophisticated" (CRM, Sales Director) market.

UK is a challenging market; one could say that it is a good warm up before going abroad. (Optolect, Managing Director)

Sportswear interviewees, a manufacturer of skiing and hiking sportswear with a well-established UK market presence, perceived that customer preferences and product knowledge are rather stable in the British market as compared to other industries. Independent of their domestic sales intensity, all case companies considered domestic market activities as an important asset.

Domestic market success is a matter of prestige. (Sportswear, Managing Director)

The domestic market can be the easy target for the low targeting firms as internationalization can be the easy failure. But the domestic operations can be a source of competitive advantage that can support international performance essentially. (MED, Sales Director)

When we were analyzing the market exploitation and exploration synergies and tensions across the case firms, three overarching themes repeatedly emerged as an answer to our research question. These were: ambidexterity, networks and organizational market information processes (OMIP). That is, ambidexterity, networks and OMIP explain the emergence of synergies and tensions within the combinations of domestic and international market exploitation and exploration of our case firms. Specifically, the actors were fully aware of these complementarities and tradeoffs. They leveraged the synergies through integration tactics and managed the tensions through differentiation tactics. Their integration and differentiation efforts were anchored to ambidexterity, networks and OMIP. Integration involved engagement with both poles of a combination of domestic and international market exploitation and exploration, whereas differentiation entailed engagement with either poles of a combination (cf. Lawrence \& Lorsch, 1967; Jansen et al., 2009) (see Figure 2). In this context of integration and differentiation, we leveraged past studies to further interpret our findings.

As far as ambidexterity is concerned, integration practices of our case firms embodied unity of effort through which top management dealt with the contradictory knowledge processes of domestic and international market exploitation and exploration (cf. Lubatkin et al., 2006). Conversely, differentiation practices ensured focus on either of these processes. In line with Gibson \& Birkinshaw (2004), this unilateral focus entailed isolation and hindered coordination between opposing exploitation-exploration efforts. As Andriopoulos \& Lewis (2009) claimed, whilst differentiation tactics compartmentalize exploitation and exploration opportunities, integration tactics emphasize interdependence, foster both/and thinking and enable coordination between exploitation and exploration.

Taking a closer look at the role of networks, integration efforts on behalf of our case firms pointed to concurrent and balanced presence of both existing and new partners at the industrial network level (cf. Lin et al., 2007). Our companies that combined exploitation and exploration attained a central position at the network structure and enjoyed competitive advantage (cf. Riccaboni \& Moliterni, 2009). Similar to Turner et al.'s (2013) arguments, we show that the integration efforts of our case firms encompassed complex inter- and intra-organizational networks of strong and weak ties for effective dissemination of market information. Conversely, differentiation efforts favored either an exploitative and collaborative approach to networks of strong ties or an exploratory and entrepreneurial approach to networks of weak ties (cf. Burt, 1992; Granovetter, 1973; Reagans \& McEvily, 2003). Indeed, Tiwana (2008) asserted that a network of strong ties has a greater capacity to exploit new ideas and lower capacity to generate them, whereas a network of weak ties and structural holes has a greater capacity to generate innovative ideas and lower capacity to implement them. 
With regard to organizational market information processes, OMIP comprise acquisition, dissemination, sensemaking and application of market information (Moorman, 1995). In a similar vein with Kyriakopoulos \& Moorman (2004), we find that the integration tactics of our case firms included the creation of critical market information flows between both poles of a combination of domestic and international market exploitation and exploration. On the other hand, the differentiation tactics involved an OMIP emphasis on either existing (domestic/international) or new (domestic/international) markets, which improved either exploitation or exploration (Vorhies et al., 2011). Similar to Lisboa et al. (2013), our findings highlight the value of OMIP in balancing domestic and international market exploitation and exploration, leading to mutually reinforcing relationships. By means of OMIP integration tactics, the refinement and deployment of knowledge about existing markets (exploitation) supported the creation of knowledge about new markets (exploration), and in turn market exploration helped the case firms leverage knowledge about current markets.

In the following three subsections, we present and discuss our findings, which are organized around the three cross-case themes of ambidexterity, networks and OMIP. We unpack the market exploitation and exploration synergies and tensions of the case firms, and illustrate the combinations of exploitation and exploration between and within their domestic and international markets by means of informants' quotes, cross-case comparison tables and diagrams (cf. Miles \& Huberman, 1994).

\subsection{Ambidexterity}

MED was a leading designer, manufacturer and marketer of vascular products for the surgical treatment of cardiovascular disease. MED was the market leader in Japan, the UK and many European countries. The firm's substantial sales and technological expertise were recognized in the UK and Japan. The company received four British Queen's Awards for export achievement, a British Queen's Award for technological achievement, and an export award from the Japanese External Trade Organisation. Although the company had a strong international presence with over $85 \%$ of all its production being exported in more than 60 countries, it excelled in its domestic market as well.

During a three-year period, which was proved important to the growth of the company, three innovative products for systemic vascular repair were launched; they targeted the same market segment and they were based on the same gelatin sealed, woven polyester graft technology. The company gained approval for marketing these products in the highly regulated Japanese and U.S. markets. The entry into those two important markets increased sales by $71 \%$ in four years. The way the company simultaneously managed the regulatory processes in both international markets illustrates important synergies and integration tactics with reference to ambidexterity.

We certainly prioritized the U.S. and Japan. The top management team led and coordinated the whole effort. [pause] The key thing was [that] we approached those two markets strategically. First, we passed the U.S. premarket and postmarket controls for product A, and the [U.S.] premarket controls for Product B. Then, we entered the U.S. postmarket approval and at the same time the Japanese premarket approval of Product B. Second, we leveraged our international network of doctors, especially during the approval of Product C (MED, Sales Director)

This quote exemplifies MED's integration efforts to ensure simultaneous and sufficient engagement with both international market exploitation and international market exploration (cf. Levinthal \& March, 1993). The top management team identified similarities between the U.S. and Japanese regulatory processes. It targeted the generation of synergies between the two key markets in order to secure first mover advantage, which is an important determinant of competitiveness in this industry. The objective was to generate reliable clinical evidence that could simultaneously be used in both markets. Submission of clinical evidence was an essential requirement in both the premarket and the postmarket regulatory phases. Gibson \& Birkinshaw (2004) argued that the top management team fosters contextual ambidexterity through encouraging alignment and adaptability 
to thrive simultaneously. In this respect, MED's top management developed a supportive behavioral context to integrate exploitation and exploration between the U.S. and Japanese markets. The Sales Director described the integration tactics as follows: "...right mix of competent people, coordination, trust and realistic timeline. The top management team took on networking with external stakeholders".

In more detail, the company developed and utilized a network of reputable research institutions and funding bodies as co-investigators and co-funders in Japan and the U.S.. MED's market activities in the U.S. preceded by 11 months; they included the successful premarket and postmarket approval of Product A and the successful premarket approval of Product B. MED designed, conducted and published clinical research on its Product B as part of submitting evidence to both the Japanese premarket and the U.S. postmarket regulatory controls. One Japanese and two American highly regarded research institutions participated and co-funded that project. As a result, the refinement and deployment of existing market knowledge about the U.S. postmarket approval phase both benefited from and supported the generation of new market knowledge about the Japanese premarket approval phase. This finding also suggests that the scope of definitions of market exploitation and exploration (Kyriakopoulos \& Moorman, 2004; Voss \& Voss, 2013) can be extended to include market knowledge about regulations (see p.6).

Figure 3 highlights the combinations of exploitation and exploration between and within domestic and international market activities that are analyzed in this section. The next combination, which further exemplifies ambidexterity, concerns the case study of Sportswear.

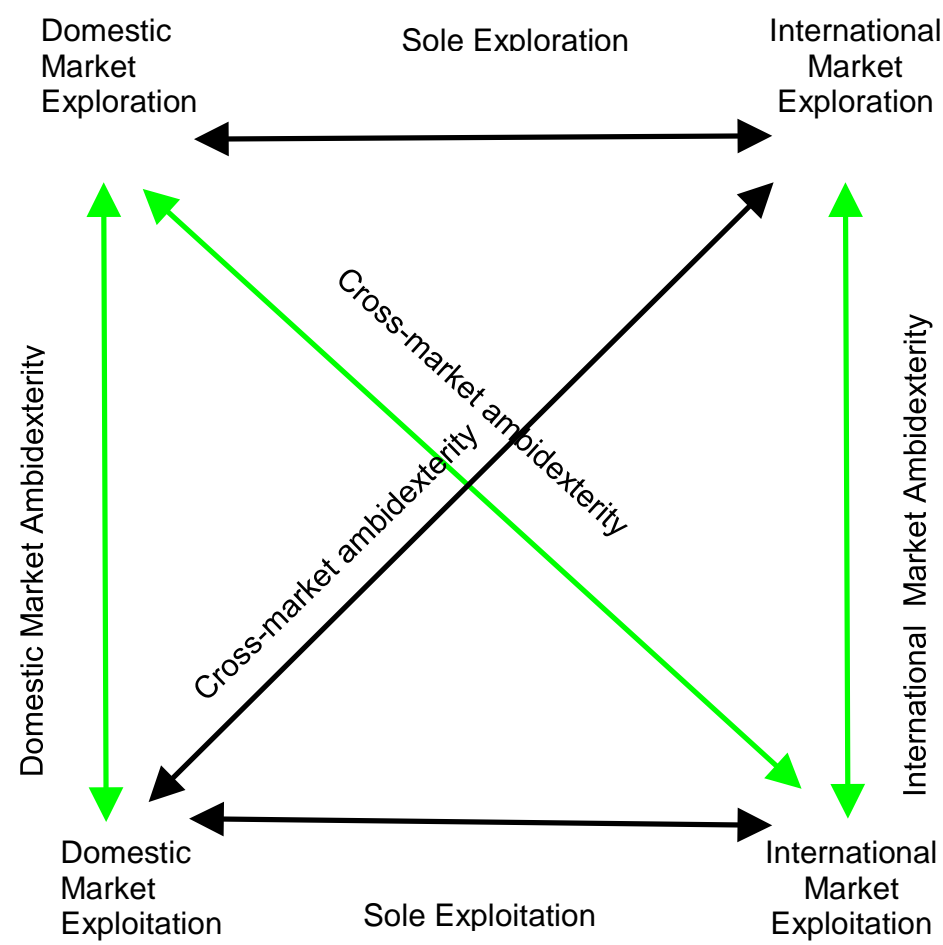

Fig. 3. Case study findings: ambidexterity 
Sportswear designed manufactured and marketed high-performing but reasonably priced sportswear, footwear and accessories for leisure and outdoor activities, particularly for skiing and hiking, for nearly 50 years. Whilst Sportswear was a recognizable brand in the UK and major international markets, its strongest market and profit sanctuary was the UK. Despite being an early internationalizer, its more-than-45-year international expansion was mostly incremental and risk averse (i.e., consolidation in existing markets before new market entry; selection of new, psychically close, international markets; and gradually increasing degree of complexity of market entry modes). Lately, Sportswear was experiencing accelerated international growth. The company was awarded the UK Fashion Exports Award for three consecutive years and it was announced Overall Best Business by a UK Chamber of Commerce. Owing to its accelerated international growth, it soon became apparent that the company had to reorganize its wholesale and retail market activities. The existing management and control systems could not serve the company any more. Before restructuring, the company experienced tensions between and within its domestic and international market activities. A differentiation practice, which was employed in order to manage these tensions, was the separation of exploration and exploitation. This differentiation practice and associated tension between domestic market exploration and international market exploitation are explained below.

Sportswear was committing significant effort to match new domestic market opportunities in fitness, cycling and running clothing with generation of corresponding new market knowledge about UK customers' preferences and competitors' activities in this market segment. The sales \& marketing team separated (and favored) this domestic market exploration project from an international market (Canada) project, which had originally commenced five years ago.

In particular, five years ago Sportwear had created its own branded retail outlets in Canada (international market exploration). Concurrently with the above mentioned domestic market exploration project, Sportswear wanted to make new and renovate its existing retail outlets in Canada (international market exploitation) ${ }^{2}$. This international market exploitation project concerned the development of knowledge about customers \& competitors and use of that knowledge in the expansion \& improvement of own branded retail outlets in Canada.

In order to cope with the inefficient allocation of resources between the two projects, the sales \& marketing team favored the domestic market exploration project. A sales \& marketing member of staff commented on this differentiation practice: "Far too many [people] had to work in both projects. Inevitably we had to make a choice based on our targets". As a result, the international project did not meet the initial deadlines. Indeed, separation of exploitation and exploration helps cope with bounded rationality, but may lead to further isolation and lack of coordination (Gibson \& Birkinshaw, 2004).

We have improved our shop design and put a new franchise model in place. Still, we need to restructure wholesaling and retailing. The new IT platform will help but there is more to that. We need to improve communication, coordination and informed decisions across our markets. (Sportswear, Sales Director)

Table 5 summarizes the case study findings of this section. The insights into the last exploitationexploration combination, which also elucidates the role of ambidexterity, refer to the case of CRM.

\footnotetext{
${ }^{2}$ We appreciate the comments of one of our anonymous reviewers in assisting us in highlighting the sequence of exploitation and/or exploration in Section 5.
} 


\begin{tabular}{|c|c|c|c|}
\hline Finding & $\begin{array}{l}\text { Market exploitation - } \\
\text { exploration } \\
\text { combinations } \\
\text { (type of market } \\
\text { knowledge involved) }\end{array}$ & Synergies / tensions & $\begin{array}{c}\text { Integration / differentiation } \\
\text { tactics }\end{array}$ \\
\hline MED 1 & $\begin{array}{l}\text { International market } \\
\text { exploitation - } \\
\text { international market } \\
\text { exploration } \\
\text { (market regulations) }\end{array}$ & $\begin{array}{l}\text { Synergies between submission of evidence to } \\
\text { premarket regulatory controls in a new key } \\
\text { international market (Japan) and submission of } \\
\text { evidence to postmarket regulatory controls in an } \\
\text { existing key international market (U.S.) }\end{array}$ & $\begin{array}{l}\text { Integration: development of } \\
\text { a supportive behavioral } \\
\text { context with reference to } \\
\text { team dynamics, team } \\
\text { competence, coordination, } \\
\text { trust and realistic targets }\end{array}$ \\
\hline SW 1 & $\begin{array}{l}\text { Domestic market } \\
\text { exploration - } \\
\text { international } \\
\text { market exploitation } \\
\text { (customers and } \\
\text { competitors) }\end{array}$ & $\begin{array}{l}\text { Tensions between creation of knowledge about } \\
\text { customers' preferences \& competitors' activities in a } \\
\text { new domestic market and development of } \\
\text { knowledge about customers \& competitors and use } \\
\text { of that knowledge in the expansion \& improvement } \\
\text { of own branded retail outlets (existing international } \\
\text { market - Canada) }\end{array}$ & $\begin{array}{l}\text { Differentiation: separation } \\
\text { of exploration and } \\
\text { exploitation to cope with } \\
\text { inefficient allocation of } \\
\text { resources between the two } \\
\text { processes }\end{array}$ \\
\hline CRM 1 & $\begin{array}{l}\text { Domestic market } \\
\text { exploitation - } \\
\text { domestic market } \\
\text { exploration } \\
\text { (customers and } \\
\text { partners) }\end{array}$ & $\begin{array}{l}\text { Synergies between refinement \& use of knowledge } \\
\text { about a client (existing domestic market) and } \\
\text { generation of knowledge about a new partner (new } \\
\text { domestic market) }\end{array}$ & $\begin{array}{l}\text { Integration: socialization } \\
\text { and team-building practices }\end{array}$ \\
\hline
\end{tabular}

CRM was recognized as a leading customer-centric technology provider both in the UK and internationally. CRM was renowned for its award-winning customer intelligence software suite that managed sales interactions and front office customer service, while reducing operational costs. Although the company had clients of diverse size and industries, its customer focus was on large multinationals that belonged to the industries of financial services, retail telecommunications, retail energy, and consumer goods. CRM often worked with complementary partners and offered highly differentiated products. For instance, CRM and a UK SME (Partner A) comprised a project team that developed a product offering for a UK retail energy company. This tailored product offering combined consultancy services and software solutions on reducing customer management costs.

CRM and Partner A leveraged synergies between domestic market exploitation and domestic market exploration through socialization and team-building practices. Socialization and teambuilding promote shared values and facilitate coordination (Ghoshal \& Bartlett, 1997). Indeed, toward the end of the project, the joint project team met more often to discuss their interactions with the client, and the possibility of expansion of the current assignment for three additional years to include complementary support services (domestic market exploitation). Those meetings revealed useful information about another UK SME (Partner B). Partner A had a joint venture with Partner B, while CRM was looking for new market opportunities in the UK transportation industry. Partner B was described as a reliable partner that had provided data mining software to a major UK train operating company. Subsequently, Partner A brought CRM in contact with Partner B, and the three companies later formed a successful joint venture with a focus on product offerings for the UK transportation industry (domestic market exploration). 
Whereas such examples depict synergies and tensions revolving around ambidexterity, we now examine the role of networks and associated integration and differentiation efforts.

\subsection{Networks}

Partnership A brought Partnerships B and C. This happens all the time. ... Market opportunities are born in project meetings. (CRM, UK Project Manager)

CRM considered that inter-firm collaboration was vital in delivering a complete and innovative product package. The company's partner program drew more sophisticated customers and enabled the firm to retain high-value domestic and international customer bases over time. CRM's relationships with partnering organizations extended from licensing to combined expertise in intellectual property, technical training, and sales and marketing. At the industrial network level, CRM committed integration efforts that showcase concurrent and balanced presence of both existing and new partners (cf. Lin et al., 2007).

During the aforementioned domestic market exploitation activities (i.e., frequent meetings about the extension of their existing domestic assignment), CRM and Partner A forged stronger ties in the sense that their joint team started spending more time together and sharing more organizational resources, especially market knowledge. A natural outcome of this interaction was their plan to replicate their domestic project abroad. However, their differentiated product required international market exploration. CRM's Managing Director noted: "it would've been a stretch for our marketing \& sales teams alone given their workloads". Instead, an internationalized Irish SME (Partner C), which belonged to their partnering network, undertook the part of marketing and sales. CRM had developed weak ties with Partner C: the latter had delivered a consultancy project for CRM within a short space of time, which did not require sharing of organizational resources, such as the formation of a joint task force team. Partner C's exploration led to a French retail telecom company as the client.

Returning to MED, the company integrated domestic and international market exploitation through a network of strong ties. The latter has a greater capacity to exploit new ideas as opposed to a network of weak ties (Tiwana, 2008). MED was building a network of doctors, based in its domestic and international markets, which was providing product feedback and important market information. In particular, British surgeons were directly involved in the design and market approval of Product C in the UK and U.S.. Since Product C was the last in time of three products that targeted the same market segment, the network of UK doctors assisted the refinement of knowledge about this existing market segment in the UK and U.S. (see definitions of domestic market exploitation \& international market exploitation in pages $6 \& 12$ ). As part of research or best practice exchange that British medical doctors often do, UK doctors from MED's network was contributing to the expansion of the network in the U.S.. With regard to Product C, exploitation in the U.S. market was supported by the internationalization of MED's network of UK cardiothoracic surgeons. They brought MED in contact with U.S. surgeons and they contributed to the U.S. market approval phases in terms of research contacts and participation in MED's research.

Figure 4 depicts the combinations of domestic and international market exploitation and exploration that are discussed in this section. The next finding (SW 2) pertains to the case study of Sportswear. 


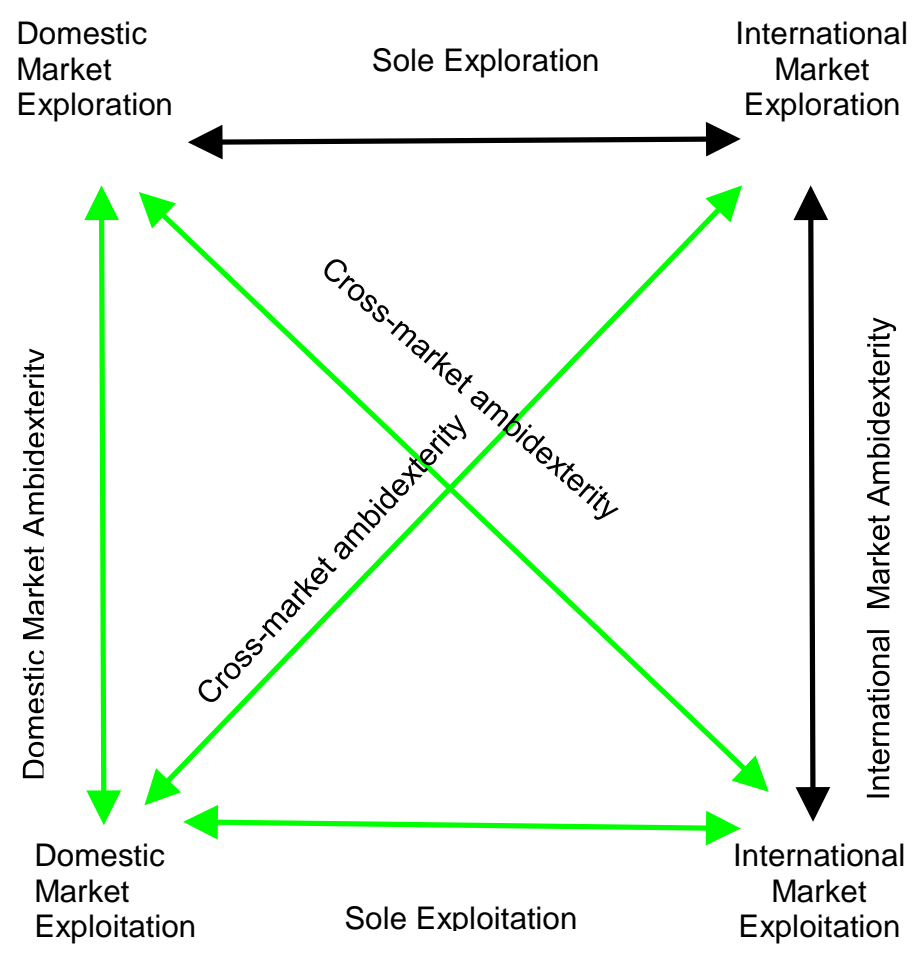

Fig. 4. Case study findings: networks

SW 2 involves tensions between domestic market exploration and domestic market exploitation. As discussed in 5.1, the domestic market exploration activities referred to creation of knowledge about UK customers' preferences and competitors' activities in the new market segment of fitness, cycling and running clothing. The other concurrent domestic market project concerned Sportswear's branded retail outlets in the UK. The first UK retail outlets had been created 25 years ago (see information on data collection in 4.2). Thus, the project of UK retail shops was in the phase of domestic market exploitation. In particular, it comprised the central expansion and improvement plan for own branded retail outlets in the UK, and related development of existing market knowledge.

Similar to SW 1, the sales \& marketing team favored the same domestic market exploration project over the same exploitation project, which in this instance concerned the domestic market. A sales \& marketing team member explained this decision, "[...] it was based on departmental objectives and team dynamics". As in SW 1, differentiation helped Sportswear cope with the opposing processes of exploration and exploitation. This tactic however offered a unilateral focus that led to delays in the exploitation project.

Specifically, Sportswear managed tensions between domestic market exploration and domestic market exploitation through favoring an exploratory and entrepreneurial approach to networks of weak ties (cf. Burt, 1992; Granovetter, 1973; Reagans \& McEvily, 2003; Tiwana, 2008). Accordingly, the exploration efforts mainly benefited from the network of weak ties (as opposed to strong ties among company staff) with UK agents and personnel of the own branded UK outlets. This network of weak ties fed the sales \& marketing team and the exploration process with new ideas. It showed great capacity to generate entrepreneurial and innovative ideas.

Table 6 brings together the case study findings of this section. Last, insights into the network of Optolect are discussed. 
Table 6

Case study findings: networks

\begin{tabular}{|c|c|c|c|}
\hline Finding & $\begin{array}{l}\text { Market exploitation - } \\
\text { exploration combinations } \\
\text { (type of market } \\
\text { knowledge involved) }\end{array}$ & Synergies / tensions & $\begin{array}{c}\text { Integration / differentiation } \\
\text { tactics }\end{array}$ \\
\hline CRM 2 & $\begin{array}{l}\text { Domestic market } \\
\text { exploitation - } \\
\text { international market } \\
\text { exploration } \\
\text { (customers and partners) }\end{array}$ & $\begin{array}{l}\text { Synergies between refinement \& use of } \\
\text { knowledge about the extension of an } \\
\text { existing domestic project and generation of } \\
\text { knowledge about a new partner and a new } \\
\text { client (new international market) }\end{array}$ & $\begin{array}{l}\text { Integration: concurrent and } \\
\text { balanced presence of both } \\
\text { existing (strong ties - Partner } \\
\text { A) and new partners (weak ties } \\
\text { - Partner C) }\end{array}$ \\
\hline MED 2 & $\begin{array}{l}\text { Domestic market } \\
\text { exploitation - } \\
\text { international market } \\
\text { exploitation } \\
\text { (customers and market } \\
\text { regulations) }\end{array}$ & $\begin{array}{l}\text { Synergies between refinement of market } \\
\text { knowledge in existing UK and U.S. market } \\
\text { segments }\end{array}$ & $\begin{array}{l}\text { Integration: } \\
\text { internationalization of } \\
\text { domestic network (strong ties) }\end{array}$ \\
\hline SW 2 & $\begin{array}{l}\text { Domestic market } \\
\text { exploration - domestic } \\
\text { market exploitation } \\
\text { (customers and } \\
\text { competitors) }\end{array}$ & $\begin{array}{l}\text { Tensions between creation of knowledge } \\
\text { about customers' preferences \& } \\
\text { competitors' activities in a new domestic } \\
\text { market and development of knowledge } \\
\text { about customers \& competitors and use of } \\
\text { that knowledge in the expansion \& } \\
\text { improvement of own branded retail outlets } \\
\text { (existing domestic market activity) }\end{array}$ & $\begin{array}{l}\text { Differentiation: focus on } \\
\text { exploration; exploratory and } \\
\text { entrepreneurial approach to } \\
\text { networks of weak ties (agents } \\
\text { and personnel of own retail } \\
\text { outlets) }\end{array}$ \\
\hline OPT 1 & $\begin{array}{l}\text { International market } \\
\text { exploitation - domestic } \\
\text { market exploration } \\
\text { (customers, competitors, } \\
\text { partners) }\end{array}$ & $\begin{array}{l}\text { Synergies between development of market } \\
\text { knowledge about medical devices (existing } \\
\text { international market segment in the U.S.) } \\
\text { and creation of market knowledge about } \\
\text { automation (new domestic market segment) }\end{array}$ & $\begin{array}{l}\text { Integration: inter- and intra- } \\
\text { organizational networks of } \\
\text { strong and weak ties for } \\
\text { effective market sharing }\end{array}$ \\
\hline
\end{tabular}

Optolect was a university spin-off that was founded as a compound semiconductor foundry with a specific focus on wafer growth and processing, and fabrication of optical device structures, mainly for the industries of telecommunications and medical devices. Optolect provided a complete range of specialized services from product design and manufacturing, to device characterization and optimization, reliability testing and wafer validation. When a new high-profile sales director, with significant international experience and contacts, had been appointed, he initially concentrated on improving international market activities, especially in the important to this industry U.S. market. While the new sales director was working closely with staff to improve coordination, communication and sharing of information, Optolect formed an important partnership with a U.S. company, which was a provider of technology consultancy solutions, so as to assist Optolect in further penetrating the existing U.S. market segment of medical devices.

Optolect leveraged synergies between international market exploitation (existing U.S market segment of medical devices) and domestic market exploration (new UK market segment of automation ) by means of intra- and inter- organizational networks of weak and strong ties (cf. Turner et al., 2013). The network of strong ties comprised the knowledge sharing relationships among Optolect's top management and its UK \& U.S. sales staff. The network of weak ties encompassed the knowledge sharing relationships between Optolect (including top management, UK \& U.S. sales teams) and the new partner (including top management, sales \& marketing people and partners). Through this complex web of U.S. and UK knowledge sharing relationships, Optolect developed market knowledge about U.S. customers and competitors into its existing U.S market segment of 
medical devices. Notably, Optolect had firstly explored the U.S market segment of medical devices two years earlier, exhibiting mediocre performance until the aforementioned international market exploitation project. As for the domestic market exploration project, the market channels of the U.S. partner assisted Optolect in creating market knowledge and expanding in the new market segment of automation. Optolect had had no prior activities in automation; it had mainly operated in telecommunications and medical devices across markets.

Results from the case of Optolect concluded this section, which explored the role of networks. Results from the same case study also initiate the next section. Organizational market information processes throw more light on Optolect and Sportswear's synergies, and on Infosyst's tensions.

\subsection{Organizational market information processes (OMIP)}

Market information is an important decision tool. ... it [the U.S. partnership] was a strategic choice. ... When we got into partnership, eight percent of total sales were made in the U.S.. We reached 15 percent in three years. ... Partner X [the U.S. partner] helped us penetrate the U.S. medical device industry further and enter the automation industry in the U.S. and UK. (Optolect, Managing Director)

Optolect's top management team applied more emphasis on market information after the new Sales Director had joined. He introduced new reporting systems concerning acquisition, dissemination, sensemaking and application of market information (Moorman, 1995). This systemization of market information processes equipped Optolect with the integration tactics to leverage synergies between international market exploitation and exploration. Critical market information flows between the contradictory processes of international market exploitation and exploration inextricably intertwined and they were supported by information from the new U.S. partner. Optolect's U.S. sales team initially acquired information on the partner's market activities; it disseminated this information to the top management team and UK headquarters sales team; they subsequently evaluated and acted on this information.

Stemming from the improvement of its OMIP, Optolect's integration tactics enabled the company to process information about the existing and new market segments together, and to become aware of the potential synergies. The company could then pursue both international market exploitation (U.S. medical devices) and exploration (U.S. automation) with the aid of the U.S. partner and its market channels. Accordingly, Optolect developed market knowledge about access to new customers into its existing U.S market segment of medical devices. As discussed earlier, Optolect had firstly explored the U.S market segment of medical devices two years before forming the partnership with the U.S. company. In the concurrent international market exploration project, the market channels of the U.S. partner assisted Optolect in creating market knowledge about access to new customers in the new U.S. market segment of automation. The U.S. partner' assistance was essential because Optolect had had no previous market experience in automation. The information effects of the collaboration with the U.S. partner transformed the exploitation-exploration combination from, by definition, contradictory to mutually reinforcing.

Figure 5 indicates the combinations of domestic and international market exploitation and exploration that are analyzed in this section. The combination of international market exploitation and exploration is covered in two findings (i.e., OPT 2 and INF 2). The next finding applies to the case study of Sportswear. 


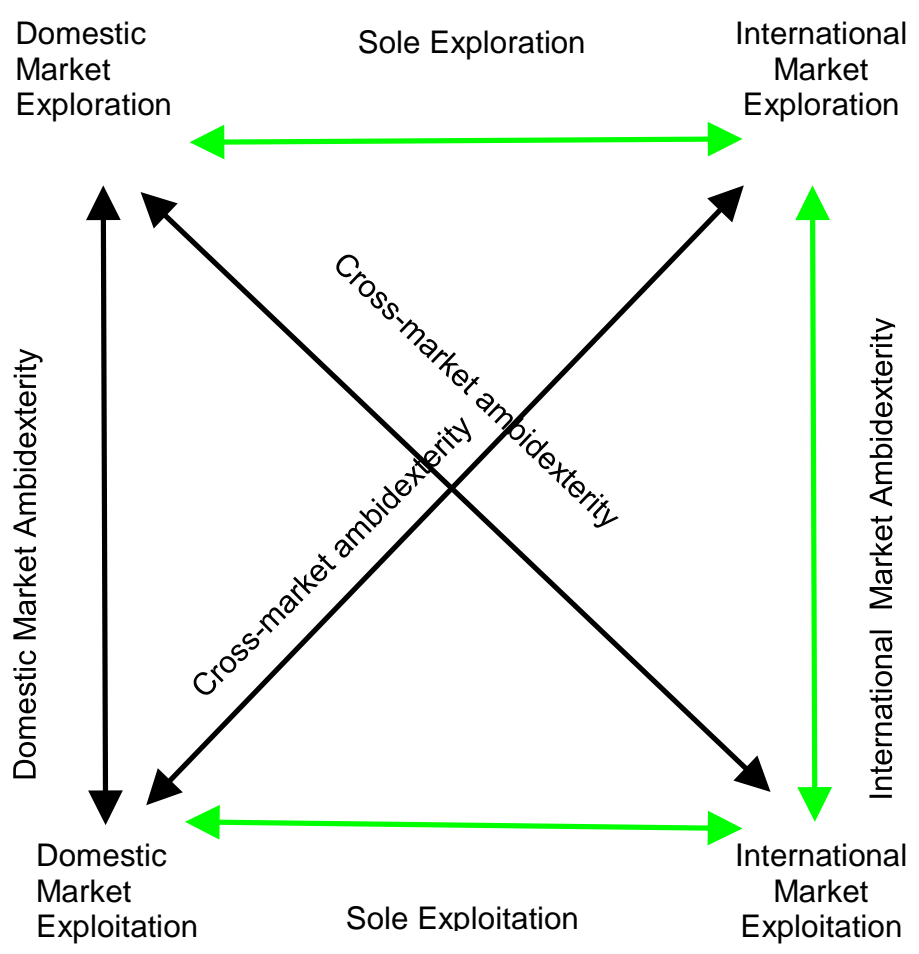

Fig. 5. Case study findings: organizational market information processes (OMIP)

Sportswear intensified its OMIP and scaled up domestic market exploration in the new segment of fitness, cycling and running clothing. The objective was to generate market knowledge about a common product line among the UK, U.S. and Germany. A project team from Sportswear's UK marketing and sales assumed the integrative role of gathering, transforming, disseminating and utilizing relevant market information (cf. Kyriakopoulos \& Moorman, 2004; Moorman, 1995). The intricacies of the integrative efforts lay in the multidimensionality of the project. Owing to its expertise in UK marketing and sales, the core team distinguished and paid attention to the domestic and the international idiosyncrasies of the project. Indicatively, it had to make sense of market information from diverse sources of domestic and international market information, including own marketing and sales staff, franchisees, agents and consultants. Depending on the source, the core project team was holding separate meetings with one or more sources of market information, followed by a core team meeting; if necessary, the core team was returning to the source(s) for clarification. The Sales Director commented on the alternate meetings, "going back and forth was time-consuming but necessary to put the pieces of the puzzle together". Overall, the integration practices reflected interpretation and synthesis of critical market information through an iterative process of information exchanges between key sources of domestic and international market intelligence.

Table 7 outlines the case study findings of this section. Insights into the role of OMIP in Infosyst's tensions between domestic and international market exploitation and exploration draw the section to a close. 
Table 7

Case study findings: organizational market information processes (OMIP)

\begin{tabular}{|c|c|c|c|}
\hline Finding & $\begin{array}{l}\text { Market exploitation - } \\
\text { exploration combinations } \\
\text { (type of market } \\
\text { knowledge involved) }\end{array}$ & Synergies / tensions & $\begin{array}{c}\text { Integration / differentiation } \\
\text { tactics }\end{array}$ \\
\hline OPT 2 & $\begin{array}{l}\text { International market } \\
\text { exploitation - } \\
\text { international market } \\
\text { exploration } \\
\text { (customers, competitors, } \\
\text { partners) }\end{array}$ & $\begin{array}{l}\text { Synergies between development of market } \\
\text { knowledge about access to new customers } \\
\text { (existing international market segment in } \\
\text { the U.S.) and creation of market knowledge } \\
\text { about access to new customers (new } \\
\text { international market segment in the U.S.) }\end{array}$ & $\begin{array}{l}\text { Integration: creation of critical } \\
\text { market information flows } \\
\text { between exploitation and } \\
\text { exploration, supported by } \\
\text { information from the new } \\
\text { partner }\end{array}$ \\
\hline SW 3 & $\begin{array}{l}\text { Domestic market } \\
\text { exploration - } \\
\text { international market } \\
\text { exploration } \\
\text { (customers and } \\
\text { competitors) }\end{array}$ & $\begin{array}{l}\text { Synergies between creation of knowledge } \\
\text { about customers' preferences \& } \\
\text { competitors' activities in a new domestic } \\
\text { market segment and its corresponding } \\
\text { international one }\end{array}$ & $\begin{array}{l}\text { Integration: interpretation and } \\
\text { synthesis of critical market } \\
\text { information through an } \\
\text { iterative process of information } \\
\text { exchanges between key sources } \\
\text { of domestic and international } \\
\text { market intelligence }\end{array}$ \\
\hline INF 1 & $\begin{array}{l}\text { International market } \\
\text { exploitation - domestic } \\
\text { market exploitation } \\
\text { (partners and customers) }\end{array}$ & $\begin{array}{l}\text { Tensions between development \& use of } \\
\text { knowledge about an international partner } \\
\text { (existing international market) and } \\
\text { refinement of knowledge about customers } \\
\text { (existing domestic market) }\end{array}$ & $\begin{array}{l}\text { Differentiation: OMIP focus on } \\
\text { the U.S. existing market } \\
\text { segment that favored and } \\
\text { supported international market } \\
\text { exploitation }\end{array}$ \\
\hline INF 2 & $\begin{array}{l}\text { International market } \\
\text { exploitation - } \\
\text { international market } \\
\text { exploration } \\
\text { (partners) }\end{array}$ & $\begin{array}{l}\text { Tensions between development \& use of } \\
\text { knowledge about an international partner } \\
\text { (existing international market) and creation } \\
\text { of knowledge about an international partner } \\
\text { (new international market) }\end{array}$ & $\begin{array}{l}\text { Differentiation: Supported by } \\
\text { the processes of acquisition and } \\
\text { sensemaking, application of } \\
\text { market information about the } \\
\text { U.S. market segment and } \\
\text { partner informed decisions } \\
\text { concerning legal and training } \\
\text { aspects of the partnership }\end{array}$ \\
\hline
\end{tabular}

Infosyst was a provider of information systems and was specialized in streamlining airport operations, online customer self-care, and pipeline monitoring \& management for oil and gas firms. Infosyst's focus mostly resembled that of a domestic venture (cf. McDougall, 1989): sales were mainly achieved in the domestic market; the loci of revenues were its leading-edge patented technology and emphasis on product exploitation, domestic market exploration and domestic market exploitation. The top management team consisted of engineers who had stronger technical expertise than international managerial experience and orientation. Past international business research showed a positive relationship between experience in international markets and international performance (Cavusgil \& Zou, 1994). As Andersson (1990) and McDougall et al. (2003) also noted, technical entrepreneurs are mainly interested in product and production development, and internationalization may occur as a result of these activities. Infosyst went abroad 10 years after establishment, and its overall international growth was impromptu rather than planned. Although one fifth of total sales was international, international sales largely resulted from client-following and strong product offerings.

Infosyst gained access to significant international market resources and experience in the U.S. market segment of aviation through a U.S. partner. Before this partnership, three U.S. aviation assignments had preceded. The formation of the U.S. partnership aimed to further and systematically develop Infosyst's knowledge about the existing U.S. market segment of aviation (international 
market exploitation). However, Infosyst applied differentiation and favored international market exploitation at the expense of concurrent projects of domestic market exploitation and international market exploration.

With respect to domestic market exploitation, because Infosyst applied more emphasis on the U.S. existing market segment and increased its visits to the U.S. partner, there were delays in marketing the software upgrades for two of its main domestic clients in aviation and oil \& gas production. Aviation and oil \& gas had historically been Infosyst's first domestic market segments, and those two clients had been among Infosyst's initial five domestic clients. When it was finalizing the legal aspects of the U.S. partnership and the training program of the partner's staff, the top management team could not frequently meet with the domestic clients who were used to only interact with the managing and sales directors. As Infosyst could not simultaneously manage the OMIPs of the UK product upgrades and in turn feed the product development team, those domestic market exploitation efforts were delayed.

With regard to international market exploration, while Infosyst was formalizing its collaboration with the U.S. partner, Infosyst was also trying to find a partner in Japan and to realize a new market opportunity in aviation. Nevertheless, it applied a differentiation approach to OMIP so as to cope with the knowledge intensity requirements of the U.S. deal. Supported by the processes of acquisition and sensemaking (Moorman, 1995), Infosyst applied market information about the U.S. market segment and made informed decisions concerning legal and training aspects of the partnership. On the other hand, Infosyst had had no prior market experience in Japan. In seven months, the company only managed to make contacts in the Japanese governmental agencies and attend two trade fairs. It took four more months to follow up on those meetings.

Japan was important but we had to get the U.S. partnership going. (Infosyst, Managing Director)

We now step back from the case studies to discuss the implications of our findings and promising directions for future research.

\section{Discussion}

Blending international business and exploitation-exploration literature and leveraging five indepth case studies enable far-reaching theoretical and practical implications for the internationalizing firm, which revolve around ambidexterity, networks and OMIP.

This study contributes to the strand of IB research (Bell et al., 2004; Luostarinen, 1979; Nadkarni et al., 2011; Wiedersheim-Paul et al., 1978; Wolf, 1977) that establishes a clearer role for the domestic market in internationalization and advocates the need for a more comprehensive understanding of international firm growth. Although traditional IB theories and process models consider the domestic market as the starting basis of internationalization, the supporting and constraining mechanisms and processes between domestic and international market activities remain in the background. Given the value of knowledge in internationalization, we take a theoretical approach that is not only confined to domestic and foreign market issues, but also embeds the processes of exploitation and exploration in this investigation. Our findings indicate that ambidexterity, networks and organizational market information processes (OMIP) explain the emergence of synergies and tensions between and within domestic and international market activities.

In particular, we unravel the six idiosyncratic combinations of exploitation and exploration that manifest between and within domestic and international markets. Accordingly, we propose that the internationalizing firm leverages synergies and manages tensions between: 
(a) Exploitation and exploration within a single (domestic or international) market domain (see (a) in Figure 6);

(b) Cross-market exploitation and exploration (see (b) in Figure 6);

(c) Sole exploitation between domestic and international markets and sole exploration between domestic and international markets (see (c) in Figure 6).

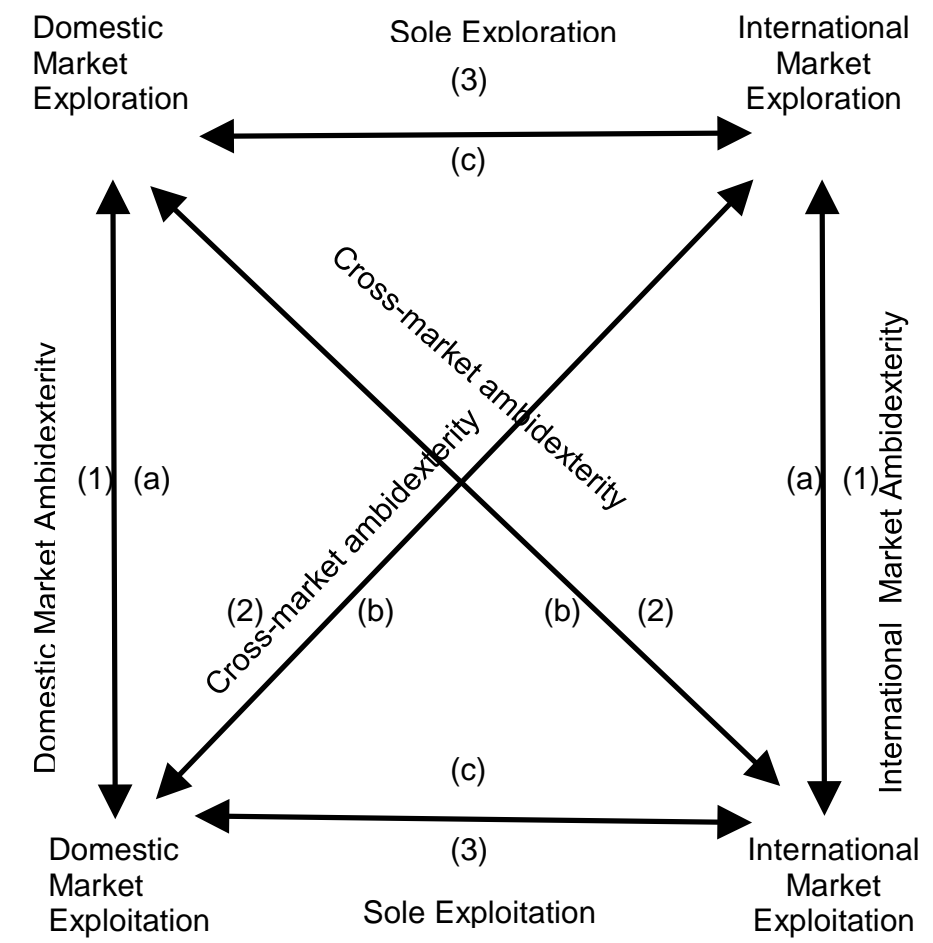

Fig. 6. Domestic and international market exploitation and exploration

While the exploitation-exploration lens has surprisingly attracted fragmentary scholarly attention in IB (Hsu et al., 2013), ambidexterity research calls for multi-level and multi-domain investigations of exploitation and exploration (Gupta et al., 2006; Raisch \& Birkinshaw, 2008; Turner et al., 2013). Our study responds by examining exploitation and exploration between and within the domestic and the international market domains. Whereas ambidexterity research mostly investigates the generic interplay between exploitation and exploration, we extend the concept of ambidexterity in two ways:

(1) Domestic or international market ambidexterity by combining exploration and exploitation within a single market domain (see (1) in Figure 6); 
(2) Cross-market ambidexterity by combining exploration of new domestic or international markets and exploitation of current international or domestic markets, respectively (see (2) in Figure 6).

Unpacking these alternative dimensions of ambidexterity, this study reinforces the value of coexisting exploitation and exploration in IB research. Whereas traditional IB theories emphasize the importance of exploitative strategies in international markets, the contemporary competitive environment necessitates a more complete understanding of the implications of ambidexterity in international business (Hsu et al., 2013; Prange \& Verdier, 2011). We show that the concurrent processes of exploitation and exploration are sources of synergies and tensions between and within domestic and international market activities. In particular, our findings uncover how the internationalizing firm leverages exploitation-exploration complementarities through integration tactics and manages exploitation-exploration tradeoffs through differentiation tactics. Differentiation ensures focus on either exploitation or exploration in either market domain. Conversely, integration encompasses unity of effort of top management to cope simultaneously with these contradictory knowledge processes. As Andriopoulos \& Lewis (2009) asserted, whilst differentiation tactics compartmentalize exploitation and exploration opportunities, integration tactics emphasize interdependence, foster both/and thinking and enable coordination between exploitation and exploration. The role of senior leadership is instrumental in leveraging exploitation-exploration synergies and managing exploitation-exploration tensions through constant reconfiguration of organizational resources (O'Reilly \& Tushman, 2008). Nevertheless, the lens of ambidexterity cannot explain the cross-market combinations of sole exploitation and sole exploration (see (3) in Figure 6), since by definition ambidexterity only explicates the interplay between exploitation and exploration.

We find that ambidexterity plays a complementary explanatory role with networks and organizational market information processes. Indeed, Stadler et al. (2014) argued that a network perspective can transcend the weaknesses of traditional approaches to ambidexterity. Our study indicates that networks and OMIP ensure an appropriate level of integration or differentiation between the examined knowledge processes, and explain the evolution of associated complementarities and tradeoffs. Network based integration efforts develop complex inter- and intra-organizational networks of strong and weak ties for effective dissemination of market information (Turner et al., 2013). OMIP based integration tactics generate critical market information flows (Kyriakopoulos \& Moorman, 2004). On the other hand, network based differentiation efforts favor either an exploitative and collaborative approach to networks of strong ties or an exploratory and entrepreneurial approach to networks of weak ties (Burt, 1992; Granovetter, 1973; Reagans \& McEvily, 2003). OMIP based differentiation tactics embed knowledge about either existing (domestic/international) or new (domestic/international) markets, improving either exploitation or exploration (Vorhies et al., 2011).

From an IB perspective, internationalization relies on both firm's knowledge processes and participation in relevant networks (Johanson \& Vahlne, 2009). Network relationships significantly influence market diversification activities during internationalization (Coviello \& Munro, 1997). Chetty \& Blankenburg Holm (2000) showed how firms' knowledge processes interact with firms' networks to extend, penetrate and integrate their international markets. This research addresses a research gap in the controversial role of domestic market knowledge processes and domestic network relationships in internationalization. Some authors (Nadkarni \& Perez, 2007; Nadkarni et al., 2011) found synergies between domestic mindsets and initial international steps of large and established domestic firms. Blomstermo et al. (2004) however indicated that prior domestic experience facilitates the international knowledge development of early internationalizers, but constrains the international knowledge development of late internationalizers. Sigfusson \& Harris 
(2013) argued that strong domestic relationships divert resources from the internationalization effort of high technology INVs. This study demonstrates that an established high technology internationalizing firm may integrate domestic and international market exploitation when a domestic network of strong ties internationalizes. In practical terms, high technology firms with established domestic and international market activities should not overlook strong domestic network relationships and should be aware that the internationalization of their domestic partners can support refinement of their domestic and international market knowledge. Even firms with high degree of internationalization, such as the cases of MED and CRM, may greatly benefit from strong domestic relationships. Complementing our work, a promising direction for future research would be the exploration of the role of weak domestic networks in international market exploration.

Furthermore, Nadkarni \& Perez (2007) found that firms with complex domestic mindsets can better conceive the type and sources of critical international market information and can hence collect it more quickly and less costly. In a similar vein, we suggest that systemization of organizational market information processes help firms be more market ambidextrous. Firms can develop appropriate reporting systems concerning collection, dissemination, analysis and use of critical market information. In this way, they can more systematically approach their market growth, and leverage synergies and manage tensions between and within their domestic and international markets. Further research could contribute a market learning model (cf. Day, 1994, 2002; Kim \& Atuahene-Gima, 2010; Liu et al., 2014; Zou \& Ghauri, 2010) to help our theoretical understanding of the complex dynamics between and within domestic and international market activities of firms. Such further research could build on our findings and the link of the exploitation-exploration literature with organizational learning (cf. Fang et al., 2010; Levinthal \& March, 1993; March, 1991). Future research should also focus on the effects of domestic market activities on international performance. At the same time, it should clarify and generalize performance implications for firms with differing organizational characteristics.

Despite its contribution, our study has a number of limitations. The validity of the findings may be restricted to the case study firms, which have placed some restrictions on the analytical generalizability. The case firms differed in terms of organizational characteristics as the market activities, challenges, and knowledge requirements are firm, industry, and context specific (Fletcher et al., 2013; Sigfusson \& Harris, 2013). Further research in other firm, market, industrial and geographical settings and larger scale studies can provide more support for the generalizability of our findings. In addition, differences should be investigated and comparisons should be made among firms in relation to these contexts, for example, in relation to firm age and size (Voss \& Voss, 2013). Furthermore, our findings concerning the role of networks should ideally have been corroborated by evidence from all the partners involved. In addition, our results, which may be limited to the case firms, have not suggested a link between product exploitation-exploration and domesticinternational market activities. Similar to McNaughton \& Bell's (2001) study, the products of each case firm did not differ between its domestic and international markets. Future studies should further elucidate the value of product exploitation and exploration in the examination of synergies and tensions between and within domestic and international market activities.

\section{Conclusions}

This paper sheds light on the role of the domestic market for the internationalizing firm. To date, IB studies have paid limited attention to this fundamental research issue (Nadkarni et al., 2011; Nadkarni \& Perez, 2007; Lu et al., 2014; Salomon \& Shaver, 2005). Through five qualitative case studies, we show that both the dynamics between domestic-international market activities and the interplay between exploitation-exploration are inherently concerned with complementarities and tradeoffs. We find that the emergence of these complementarities and tradeoffs is explained by the overarching themes of ambidexterity, networks and organizational market information processes (OMIP). We indicate that the internationalizing firm leverages synergies through integration tactics 
and manages tensions through differentiation tactics. Integration and differentiation efforts are embedded in ambidexterity, networks and OMIP. Integration involves engagement with both poles of a combination of domestic and international market exploitation and exploration, whereas differentiation entails engagement with either pole. We have sought to bring a significant yet underexplored theme to the fore and make fruitful suggestions for future research. Our findings could stimulate further research on firms with different domestic markets and organizational characteristics from our study.

\section{References}

Andersson, S. (1990). The Internationalization of the Firm from an Entrepreneurial Perspective. International Studies of Management \& Organization, 30, 63-92.

Andriopoulos, C., \& Lewis, M. W. (2009). Exploitation-Exploration Tensions and Organizational Ambidexterity: Managing Paradoxes of Innovation. Organization Science, 20, 696-717.

Autio, E., Sapienza, H. J., \& Almeida, J. G. (2000). Effects Of Age At Entry, Knowledge Intensity, And Imitability On International Growth. Academy of Management Journal, 43, 909-924.

Beamish, P. W., Craig, R., \& McLellan, K. (1993). The Performance Characteristics of Canadian versus UK Exporters in Small and Medium-sized Firms. Management International Review, 33, 121-137.

Bell, J., Crick, D., \& Young, S. (2004). Small Firm Internationalization and Business Strategy: An Exploratory Study of 'Knowledge-intensive' and 'Traditional' Manufacturing Firms in the UK. International Small Business Journal, 22, 21-52.

Bell, J., McNaughton, R., \& Young, S. (2001). 'Born-again Global' Firms: An Extension to the 'Born Global' Phenomenon. Journal of International Management, 7, 173-189.

Bell, J., \& Young, S. (1998). Towards an Integrative Framework of the Internationalization of the Firm. In Hooley, G., Loveridge, R., \& Wilson, D. (Eds). Internationalization: Process, Context and Markets. Macmillan, London, 5-28.

Blomstermo, A., Eriksson, K., \& Sharma, D. D. (2004). Domestic Activity and Knowledge Development in the Internationalization Process of Firms. Journal of International Entrepreneurship, 2, 239-258.

Burt, R. (1992). Structural Holes: The Social Structure of Competition. Harvard University Press, Cambridge, MA.

Carson, D., \& Coviello, N. (1996). Qualitative Research Issues at the Marketing - Entrepreneurship Interface. Marketing Intelligence \& Planning, 14, 51-58.

Casson, M. (1992). Internalisation Theory and beyond. In Buckley, P.J. (Eds). New Directions in International Business: Research Priorities for the 1990s. Edward Elgar, Aldershot, 4-27.

Cavusgil, S. T., \& Zou, S. (1994). Marketing Strategy-Performance Relationship: An Investigation of the Empirical Link in Export Market Ventures. Journal of Marketing, 58, 1-21.

Chetty, S., \& Blankenburg Holm, D. (2000). Internationalisation of small to medium-sized manufacturing firms: a network approach. International business review, 9, 77-93.

Cohen, J. (1960). A coefficient of agreement for nominal scales. Educational \& Psychological Measurement, 20, 37-46.

Cohen, W. M., \& Levinthal, D. A. (1990). Absorptive Capacity: A New Perspective on Learning and Innovation. Administrative Science Quarterly, 35, 128-152.

Coviello, N., \& Munro, H. (1997). Network relationships and the internationalisation process of small software firms. International business review, 6, 361-386.

Day, G. S. (1994). Continuous Learning About Markets. California Management Review, 36, 9-31.

Day, G. S. (2002). Managing the market learning process. Journal of Business \& Industrial Marketing, $17,240-252$.

Davis, C. D., Hills, G. E., \& LaForge, R. W. (1985). The Marketing/Small Enterprise Paradox: A Research Agenda. International Small Business Journal, 3, 31-42.

De Clercq, D., Sapienza, H. J., \& Crijns, H. (2005). The internationalization of small and medium-sized firms. Small Business Economics, 24, 409-419.

Diamantopoulos, A., \& Schlegelmilch, B. (1994). Linking Export Manpower to Export Performance: A Canonical Regression Analysis of European and U.S. Data. In Cavusgil, S. T., \& Axinn, C. (Eds). 
Advances in International Marketing. JAI Press, Greenwich, 161-81.

Dimitratos, P., Lioukas, S., \& Carter, S. (2004). The relationship between entrepreneurship and international performance: The importance of domestic environment. International Business Review, 13, 19-41.

Duncan, R. (1976). The ambidextrous organization: designing dual structures for innovation. In Kilmann, R., Pondy, L., \& Slevin, D. (Eds). The Management of Organization. North-Holland, New York, 167-188.

Eisenhardt, K. M., \& Bourgeois, L. J. (1988). Politics of strategic decision making in high-velocity environments: Toward a midrange theory. Academy of Management Journal, 31, 737-770.

Fang, C., Lee, J., \& Schilling, M. A. (2010). Balancing exploration and exploitation through structural design: The isolation of subgroups and organizational learning. Organization Science, 21, 625-642.

Fletcher, M., Harris, S., \& Richey Jr, R. G. (2013). Internationalization knowledge: What, why, where, and when?. Journal of International Marketing, 21, 47-71.

Ghauri, P. N. (2004). Designing and conducting case studies in international business research. In Marchan-Piekkari, R., \& Welch, C. (Eds.). Handbook of qualitative research methods for international business. Cheltenham: Edward Elgar.

Ghauri, P. N., \& Grønhaug, K. (2005). Research methods in business studies: A practical guide. Pearson Education.

Ghoshal, S., \& Bartlett, C. A. (1997). The Individualized Corporation: A Fundamentally New Approach to Management. Harper Business, New York.

Gibson, C. B., \& Birkinshaw, J. (2004). The antecedents, consequences, and mediating role of organizational ambidexterity. Academy of Management Journal, 47, 209-226.

Glaser, B. G., \& Strauss, A. L. (2009). The discovery of grounded theory: Strategies for qualitative research. Transaction Publishers.

Granovetter, M. (1973). The strength of weak ties. American Journal of Sociology, 78, 1360-1380.

Gupta, A. K., Smith, K. G., \& Shalley, C. E. (2006). The Interplay Between Exploration And Exploitation. Academy of Management Journal, 49, 693-706.

Harris, S. G., \& Sutton, R. I. (1986). Functions Of Parting Ceremonies In Dying Organizations. Academy of Management Journal, 29, 5-30.

He, Z., \& Wong, P. (2004). Exploration vs. Exploitation: An Empirical Test of the Ambidexterity Hypothesis. Organization Science, 15, 481-494.

Hsu, C., Lien, Y., \& Chen, H. (2013). International ambidexterity and firm performance in small emerging economies. Journal of World Business, 48, 58-67.

Huber, G. P., \& Power, D. J. (1985). Retrospective reports of strategic-level managers: Guidelines for increasing their accuracy. Strategic Management Journal, 6, 171-180.

Hymer, S. H. (1976). The International Operations of National Firms. MIT Press, Cambridge, Mass.

Ito, K., \& Rose, E. L. (2010). The implicit return on domestic and international sales: An empirical analysis of US and Japanese firms. Journal of International Business Studies, 41, 1074-1089.

Jansen, J. J. P., Tempelaar, M. P., Van den Bosch, F. A. J. \& Volberda, H. W. (2009). Structural differentiation and ambidexterity: the mediating role of integration mechanisms. Organization Science, 20, 797-811.

Johanson, J., \& Vahlne, J. (1977). The Internationalization Process of the Firm-A Model of Knowledge Development and Increasing Foreign Market Commitments. Journal of International Business Studies, 8, 23-32.

Johanson, J., \& Vahlne, J. E. (2009). The Uppsala internationalization process model revisited: From liability of foreignness to liability of outsidership. Journal of International Business Studies, 40, 1411-1431.

Johanson, J., \& Wiedersheim-Paul, F. (1975). The Internationalization of the Firm-Four Swedish Cases. Journal of Management Studies, 12, 305-322.

Kim, N., \& Atuahene-Gima, K. (2010). Using Exploratory and Exploitative Market Learning for New Product Development. Journal of Product Innovation Management, 27, 519-536.

Kyriakopoulos, K., \& Moorman, C. (2004). Tradeoffs in marketing exploitation and exploration strategies: The overlooked role of market orientation. International Journal of Research in Marketing, 21, 219-240.

Lawrence, P. \& Lorsch, J. (1967). Differentiation and integration in complex organizations. 
Administrative Science Quarterly, 12, 1-30.

Lazer, D., \& Friedman, A. (2007). The Network Structure of Exploration and Exploitation. Administrative Science Quarterly, 52, 667-694.

Levinthal, D. A., \& March, J. G. (1993). The myopia of learning. Strategic Management Journal, 14, 95112.

Lin, Z., Yang, H., \& Demirkan, I. (2007). The performance consequences of ambidexterity in strategic alliance formations: empirical investigation and computational theorizing. Management Science, $53,1645-1658$.

Lisboa, A., Skarmeas, D., \& Lages, C. (2013). Export market exploitation and exploration and performance. International Marketing Review, 30, 211-230.

Liu, X., Gao, L., Lu, J., \& Lioliou, E. (2014). Does learning at home and from abroad boost the foreign subsidiary performance of emerging economy multinational enterprises?. International Business Review, http://dx.doi.org/10.1016/j.ibusrev.2014.10.012

Lu, J., Liu, X., Filatotchev, I., \& Wright, M. (2014). The impact of domestic diversification and top management teams on the international diversification of Chinese firms. International Business Review, 23, 455-467.

Lubatkin, M. H., Simsek, Z., Ling, Y., \& Veiga, J. F. (2006). Ambidexterity and performance in small-to medium-sized firms: The pivotal role of top management team behavioral integration. Journal of Management, 32, 646-672.

Luostarinen, R.K. (1979). Internationalization of the Firm. Acta Acadamiae Oeconomicae Helsingiensis, Helsinki School of Economics, Helsinki.

March, J. G. (1991). Exploration and Exploitation in Organizational Learning. Organization Science, 2, 71-87.

Miles, M. B., \& Huberman, A. M. (1994). Qualitative Data Analysis. Sage, Thousand Oaks, CA.

McDougall, P. P. (1989). International Versus Domestic Entrepreneurship: New Venture Strategic Behavior and Industry Structure. Journal of Business Venturing, 4, 387-400.

McDougall, P. P., Oviatt, B. M., \& Shrader, R. C. (2003). A Comparison of International and Domestic New Ventures. Journal of International Entrepreneurship, 1, 59-82.

McGuinness, N., Campbell, N., \& Leontiades, J. (1991). Selling Machinery to China: Chinese Perceptions of Strategies and Relationships. Journal of International Business Studies, 22, 187-207.

McNaughton, R. B., \& Bell, J. (2001). Channel switching between domestic and foreign markets. Journal of International Marketing, 9, 32-47.

Moorman, C. (1995). Organizational Market Information Processes: Cultural Antecedents and New Product Outcomes. Journal of Marketing Research, 32, 318-336.

Morgan, R. E., \& Katsikeas, C. S. (1998). Exporting Problems of Industrial Manufacturers. Industrial Marketing Management, 27, 161-176.

Nadkarni, S., Herrmann, P., \& Perez, P. D. (2011). Domestic mindsets and early international performance: The moderating effect of global industry conditions. Strategic Management Journal, 32, 510-531.

Nadkarni, S., \& Perez, P. D. (2007). Prior conditions and early international commitment: The mediating role of domestic mindset. Journal of International Business Studies, 38, 160-176.

O’Reilly, C. A., \& Tushman, M. L. (2004). The ambidextrous organization. Harvard Business Review, 82, 74-81.

O’Reilly, C. A., \& Tushman, M. L. (2008). Ambidexterity as a dynamic capability: Resolving the innovator's dilemma. Research in Organizational Behavior, 28, 185-206.

Oviatt, B. M., \& McDougall, P. P. (1994). Toward a theory of international new ventures. Journal of International Business Studies, 25, 45-64.

Patton, M. Q. (2005). Qualitative research. John Wiley \& Sons, Ltd.

Pettigrew, A. M. (1990). Longitudinal Field Research on Change: Theory and Practice. Organization Science, 1, 267-292.

Piekkari, R., Welch, C., \& Paavilainen, E. (2009). The Case Study as Disciplinary Convention - Evidence from International Business Journals. Organizational Research Methods, 12, 567-589.

Prange, C., \& Verdier, S. (2011). Dynamic capabilities, internationalization processes and performance. Journal of World Business, 46, 126-133.

Raisch, S., \& Birkinshaw, J. (2008). Organizational ambidexterity: antecedents, outcomes, and 
moderators. Journal of Management, 34, 375-409.

Reagans, R., \& McEvily, B. (2003). Network structure and knowledge transfer: the effects of cohesion and range. Administrative Science Quarterly, 48, 240-267.

Riccaboni, M., \& Moliterni, R. (2009). Managing technological transitions through R\&D alliances. $R \& D$ Management, 39, 124-135.

Salomon, R., \& Shaver, J. M. (2005). Export and domestic sales: Their interrelationship and determinants. Strategic Management Journal, 26, 855-871.

Sapienza, H. J., Autio, E., George, G., \& Zahra, S. A. (2006). A capabilities perspective on the effects of early internationalization on firm survival and growth. Academy of Management Review, 31, 914933.

Sapienza, H. J., De Clercq, D., \& Sandberg, W. R. (2005). Antecedents of international and domestic learning effort. Journal of Business Venturing, 20, 437-457.

Sigfusson, T., \& Harris, S. (2013). Domestic market context and international entrepreneurs' relationship portfolios. International Business Review, 22, 243-258.

Spence, M., Orser, B., \& Riding, A. (2011). A comparative study of international and domestic new ventures. Management International Review, 51, 3-21.

Stadler, C., Rajwani, T., \& Karaba, F. (2014). Solutions to the Exploration/Exploitation Dilemma: Networks as a New Level of Analysis. International Journal of Management Reviews, 16, 172-193.

Strauss, A., \& Corbin, J. (1990). Basics of Qualitative Research. Sage, Newbury Park, CA.

Tiwana, A. (2008). Do bridging ties complement strong ties? An empirical examination of alliance ambidexterity. Strategic Management Journal, 29, 251-272.

Turner, N., Swart, J., \& Maylor, H. (2013). Mechanisms for Managing Ambidexterity: A Review and Research Agenda. International Journal of Management Reviews, 15, 317-332.

Van Maanen, J. (2011). Tales of the field: On writing ethnography. University of Chicago Press.

Vernon, R. (1966). International Investment and International Trade in the Product Cycle. Quarterly Journal of Economics, 80, 190-207.

Vorhies, D. W., Orr, L. M., \& Bush, V. D. (2011). Improving customer-focused marketing capabilities and firm financial performance via marketing exploration and exploitation. Journal of the Academy of Marketing Science, 39, 736-756.

Voss, G. B., \& Voss, Z. G. (2013). Strategic Ambidexterity in Small and Medium-Sized Enterprises: Implementing Exploration and Exploitation in Product and Market Domains. Organization Science, 24, 1459-1477.

Westhead, P., Wright, M., \& Ucbasaran, D. (2002). International market selection strategies selected by 'micro' and 'small' firms. Omega International Journal of Management Science, 30, 51-68.

Westhead, P., Wright, M., \& Ucbasaran, D. (2004). Internationalization of private firms: Environmental turbulence and organizational strategies and resources. Entrepreneurship \& Regional Development, 16, 501-522.

Wiedersheim-Paul, F., Olson, H. C., \& Welch, L. S. (1978). Pre-export activity: The first step in internationalization. Journal of International Business Studies, 8, 47-58.

Williamson, P. J. (1997). Asia's new competitive game. Harvard Business Review, 75, 55-67.

Wolf, B.M. (1977). Industrial Diversification and Internationalization: Some Empirical Evidence. Journal of Industrial Economics, 26, 177-191.

Zahra, S. A., Ireland, R. D., \& Hitt, M. A. (2000). International Expansion By New Venture Firms: International Diversity, Mode Of Market Entry, Technological Learning, And Performance. Academy of Management Journal, 43, 925-950.

Zou, H., \& Ghauri, P. N. (2010). Internationalizing by learning: the case of Chinese high-tech new ventures. International Marketing Review, 27, 223-244. 